\title{
From subduction to collision: thermal overprint of HP/LT meta-sediments in the north-eastern Lepontine Dome (Swiss Alps) and consequences regarding the tectono-metamorphic evolution of the Alpine orogenic wedge
}

\author{
Michael Wiederkehr ${ }^{1,2, *}$, Romain Bousquet $^{2}$, Stefan M. Schmid $^{1}$ \& Alfons Berger ${ }^{3}$ \\ Key words: Lepontine dome, meta-sediments, Fe-Mg carpholite, Barrovian metamorphism, high-pressure metamorphism, Alpine tectonics
}

\begin{abstract}
The Cenozoic-age metamorphic structure of the Alps consists of a throughgoing pressure-dominated belt (blueschists and eclogites) that strikes parallel to the orogen and was later truncated by two thermal domes characterised by Barrow-type metamorphism (Lepontine dome and Tauern window). This study documents for the first time that relics of Fe-Mg carpholite occur also within meta-sedimentary units that are part of the north-eastern Lepontine structural and metamorphic dome, where so far exclusively Barrovian assemblages were found. They occur in meta-sediments of both Valais Oceanderived Lower Penninic Bündnerschiefer and structurally lower Europe-derived Sub-Penninic cover nappes and slices. These high-pressure units were subsequently overprinted by a thermal event, as is documented by the growth of new minerals typical for Barrovian metamorphism.

We present evidence for a two-stage metamorphic evolution in the northern part of the Lepontine dome: (1) Early subduction-related syn-D1 (Safien
\end{abstract}

phase) HP/LT metamorphism under blueschist facies conditions $\left(350-400{ }^{\circ} \mathrm{C}\right.$ and 1.2-1.4 GPa) was immediately followed by "cold" isothermal (or cooling) decompression during D2 nappe-stacking (Ferrera phase). (2) Collisionrelated Barrovian overprint $\left(500-570{ }^{\circ} \mathrm{C}\right.$ and $\left.0.5-0.8 \mathrm{GPa}\right)$ postdates the D3 nappe-refolding event (Domleschg phase) and represents a late heating pulse, separated by D2 and D3 from the D1 high-pressure event. It occurred before and/or during the initial stages of D4 (Chièra phase) representing a second nappe-refolding event.

In discussing possible heat sources for the late Barrow-type heating pulse it is argued that heat release from radioactive decay of accreted material may play an important role in contributing much to heat production. Based on the field evidence, we conclude that heat transfer was essentially conductive during these latest stages of the thermal evolution.

\section{Introduction}

The zoning of Alpine metamorphism is rather complex, evolving over a very long period of time before, during and after the collision of Europe with Adria, i.e. from Late Cretaceous to Late Cenozoic times. Mapping of metamorphic facies in the Alps started with early pioneering studies based on the spatial distribution of index minerals and mineral assemblages (Wenk 1962; Niggli \& Niggli 1965; Trommsdorff 1966; Frey 1969; Fox 1975; Frey et al. 1980). Metamorphic maps at the scale of the Alpine orogen, showing the spatial arrangement of the different metamorphic facies types, were repeatedly synthesised and improved (Ernst 1971; Niggli \& Zwart 1973; Frey et al. 1999; Oberhänsli et al. 2004). The Cenozoic-age metamorphic pattern is characterised by a pressure-dominated belt (blueschists and eclogites) that strikes orogen-parallel but is interrupted by two thermal domes, the Lepontine dome in the Central Alps and the Tauern window in the Eastern Alps (Oberhänsli et al. 2004).

Our area of investigation is located at the NE border of the Lepontine thermal dome. There, along strike of the tectonic units, a remarkable metamorphic field gradient that ranges from pressure-dominated blueschist facies in the NE to temperature-dominated Barrovian metamorphism in the SW is observed within an amazingly short distance $(<10 \mathrm{~km}$, Fig. 1 \& 2). This allows for a clear correlation between the two metamorphic events and structures that resulted from a polyphase deformation history. Hence, the area is well suited for studying spatial and temporal relationships between these two types of metamorphism, including their relative timing in respect to discrete deformation phases linked to particular geodynamical stages.

The availability of meta-sediments all along strike facilitates the reconstruction of the metamorphic and structural evolution

\footnotetext{
${ }^{1}$ Geologisch-Paläontologisches Institut, Universität Basel, Bernoullistrasse 32, CH-4056 Basel, Switzerland. E-mail: m.wiederkehr@unibas.ch

${ }^{2}$ Institut für Geowissenschaften, Universität Potsdam, Karl-Liebknecht-Strasse 24/25, D-14476 Potsdam/Golm, Germany.

${ }^{3}$ Institut für Geologie, Universität Bern, Baltzerstrasse 3, CH-3012 Bern, Switzerland.

*Corresponding author: Michael Wiederkehr. E-mail: m.wiederkehr@unibas.ch
} 


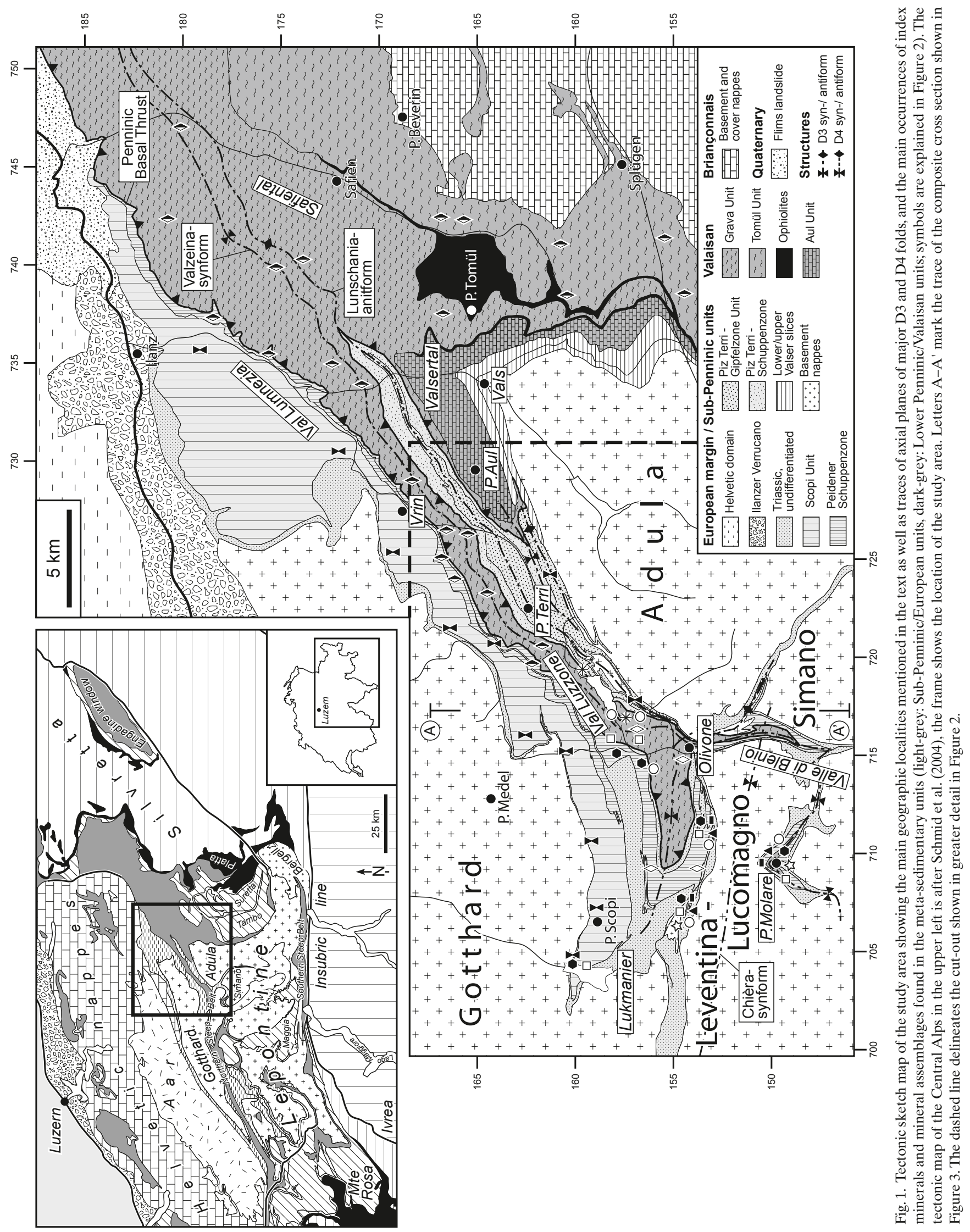


in the working area. These meta-sediments contain widespread occurrences of Fe-Mg carpholite within an orogen-parallel HP/ LT-metamorphic belt in eastern Switzerland (Grisons), characterised by blueschist facies conditions (Goffé \& Oberhänsli 1992; Oberhänsli 1994; Oberhänsli et al. 1995; Bousquet et al. 2002). Approaching the Lepontine dome, the same meta-sediments become increasingly affected by a temperature-dominated, Barrovian metamorphic event, as is documented by amphibolite facies mineral assemblages characterised by garnet, biotite, staurolite and kyanite (Chadwick 1968; Frey 1969; Fox 1975; Engi et al.1995; Frey \& Ferreiro Mählmann 1999). No evidence is available, so far, that this part of the Lepontine dome, characterised by this Barrow-type MP/MT metamorphism, could have been previously also affected by HP/LT metamorphism.

This tectono-metamorphic study primarily aims to document this transition from HP/LT blueschist facies metamorphism in the east to amphibolite-grade Barrow-type metamorphism within the Lepontine dome further west. This will allow deducing whether these two contrasting types of metamorphism evolved at the same time but differently in the different parts of the study area, or alternatively, whether they evolved during consecutive stages of the evolution of the Alpine orogen. In the second case the pressure-dominated metamorphism represents an early stage related to subduction, followed by a temperature-dominated event, as proposed by Bousquet et al. (2008). The latter, i.e. a two-stage metamorphic evolution, was also proposed for more southerly located parts of the Lepontine dome. However, the question whether the Barrow-type overprint is associated with a second and discrete heating pulse that followed high-pressure metamorphism (e.g. Engi et al. 2001), or alternatively, simply represents a late stage during isothermal decompression (e.g. Nagel et al. 2002; Keller et al. 2005) is of fundamental importance from a geodynamic point of view. Furthermore, our study will address the important key question concerning the heat source of Barrow-type Lepontine metamorphism, debated since the pioneering metamorphic studies in the Alps. While Niggli (1970) concluded that regional metamorphism in the Lepontine region is caused by tectonic burial during nappe stacking, Wenk (1970) proposed late-stage thermal doming induced by an additional (magmatic) heat source underneath a pre-existing overburden of nappes. The results presented in this study will provide insights that are of fundamental importance for understanding the thermo-mechanical evolution of collisional orogens in general.

\section{Geological setting and major tectonic units}

The investigated area is located at the north-eastern edge of the Lepontine structural dome and extends from the Lukmanierpass and Pizzo Molare areas in the west to the Safiental area in the east (Fig. 1). The Sub-Penninic nappes, interpreted as derived from the distal European margin (Milnes 1974; Schmid et al.2004), originally occupied a lower tectonic position within the working area. Among these nappes are basement nappes that predominantly consist of pre-Mesozoic igneous and metasedimentary rocks, and cover nappes forming an orogen-parallel belt of Mesozoic meta-sediments. The cover nappes are not interrupted by oblique tectonic contacts (thrusts or faults) and they overlie the pre-Mesozoic basement units or nappes (Gotthard "Massif", Leventina-Lucomagno and Simano nappes). These Sub-Penninic nappes are structurally overlain by Lower Penninic cover nappes that originated from the Valais Ocean, largely consisting of Mesozoic meta-sediments referred to as Bündnerschiefer. The front of the Adula nappe complex only reaches the southern rim of the working area. The occurrences of oceanic remnants that are imbricated with typical continental crustal rocks in the overlying Misox Zone (e.g. Partzsch 1998), and according to some authors also within the Adula-Cima Lunga nappe complex itself (e.g. Trommsdorff 1990, and references therein), indicate that the Adula nappe complex contains slivers from the continent-ocean transition between the European margin and the Valais Ocean (lithospheric mélange; Trommsdorff 1990). The Penninic Basal Thrust represents an early-stage first-order thrust along which the Valaisan Bündnerschiefer were originally thrust onto the Europe-derived Sub-Penninic units. However, this thrust was subsequently isoclinally refolded and hence penetratively overprinted by later structures. The tectonic units, subdivided following the schemes proposed by Schmid et al. (2004) and Berger et al. (2005), are mapped in Figures 1 and 2, as well as in cross section view (Fig. 3). In the following they are further described.

\subsection{Sub-Penninic basement nappes}

The Gotthard-"massif" is the lowermost thrust sheet of the Sub-Penninic nappe pile (Fig. 3) and represents a backfolded nappe front (Milnes 1974) rather than a par-autochthonous massif. This unit consists of pre-Mesozoic crystalline basement (Steiger 1962; Mercolli et al.1994) overlain in stratigraphic contact only by an extremely thin veneer of Early to Middle Triassic quartzites, occasionally also containing dolomitic marbles and/or meta-evaporites (Frey 1967).

The Lucomagno-Leventina nappe structurally overlays the Gotthard-"massif", from which it is separated by the Piora Zone, which represents an intervening Sub-Penninic cover nappe (Fig. 3). The southern realms of the LucomagnoLeventina nappe predominantly consist of Variscan orthogneiss (Leventina gneiss; Casasopra 1939; Köppel et al. 1981; Rütti et al. 2008), forming the deepest outcropping parts of the Ticino sub-dome within the Lepontine dome (Merle et al. 1989). The northern part of the Leventina-Lucomagno nappe reaches the working area and consists of Pre-Mesozoic poly-metamorphic meta-sedimentary complexes (Lucomagno crystalline; Bossard 1925, 1929; Chadwick 1968).

The next higher Sub-Penninic basement nappe, i.e. the Simano nappe, contains Caledonian to Variscan orthogneisses and pre-Mesozoic poly-metamorphic pelitic to psammitic meta-sediments (Jenny et al. 1923; Niggli et al. 1936; Keller 1968; Köppel et al. 1981). It is separated from the underlying 


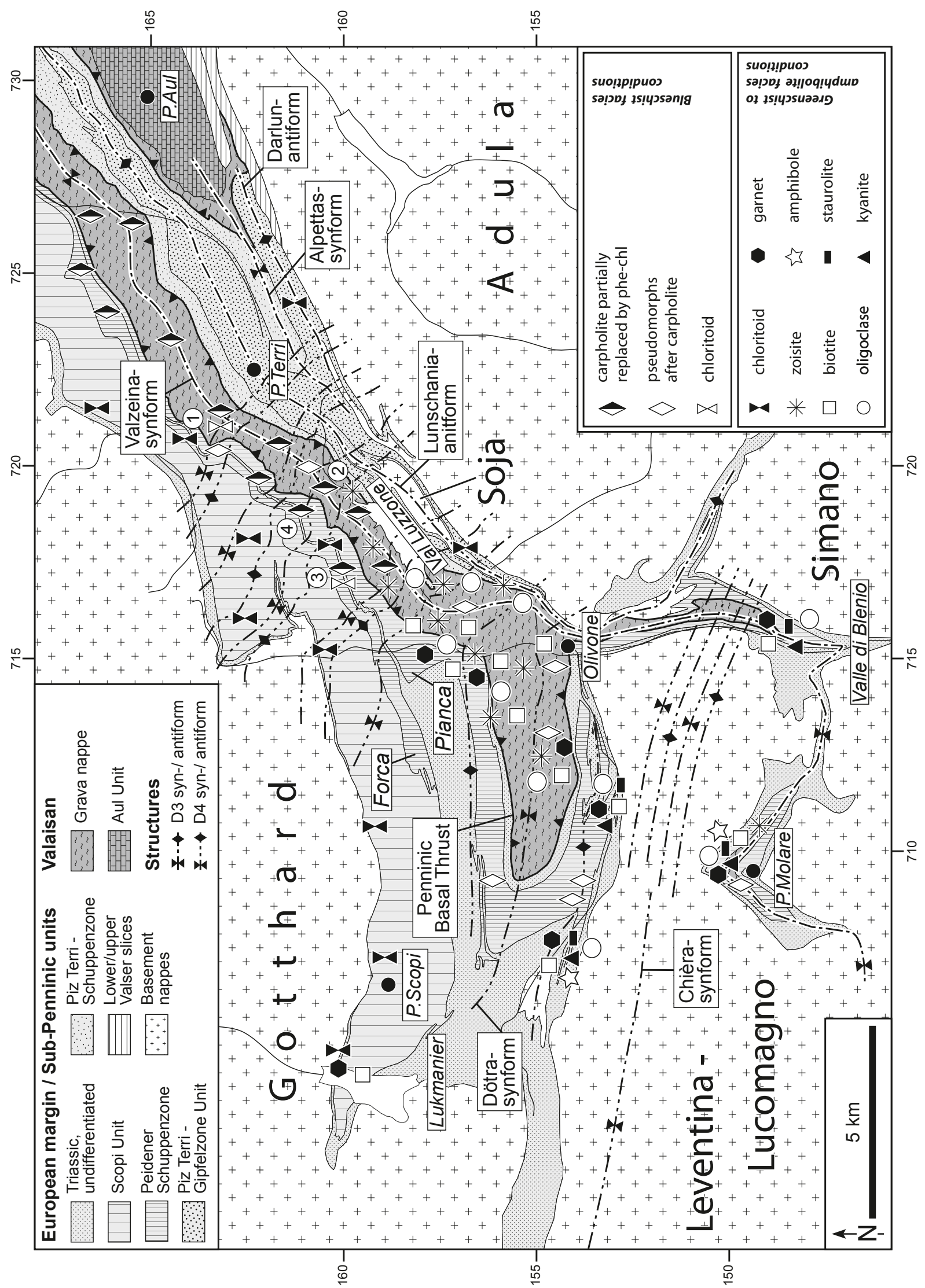

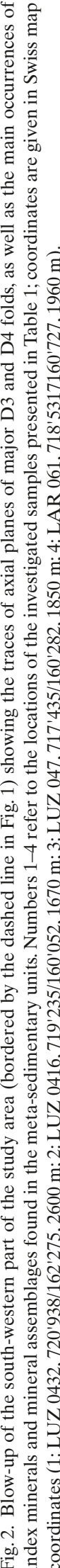




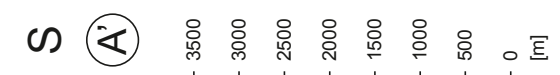

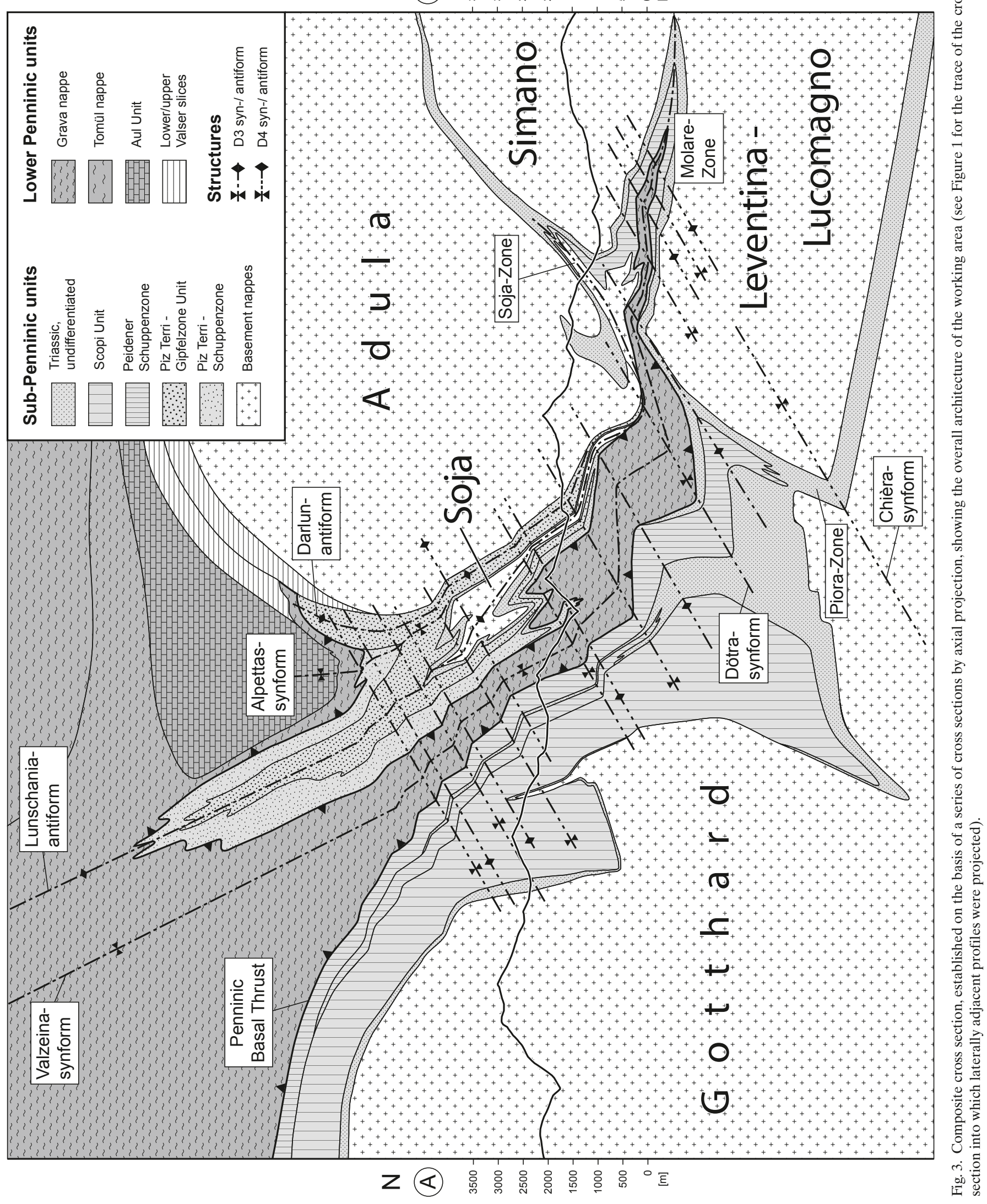


Lucomagno-Leventina basement nappe by the Molare Zone, again consisting of cover nappes (Fig. 3).

A thin sliver of pre-Mesozoic meta-sediments (locally Verrucano-type meta-conglomerates of presumed Permian age), that is part of the so-called Soja nappe (Jenny et al. 1923; Egli 1966) crops out in Val Luzzone at the front of the Adula nappe complex. This Soja nappe can be followed southwards where it is seen to separate the Simano nappe from the Adula nappe complex (Soja Zone of Fig. 3). Most authors correlate the Soja nappe with the Lebendun nappe west of the Lepontine dome (Burckhardt 1942; Egli 1966).

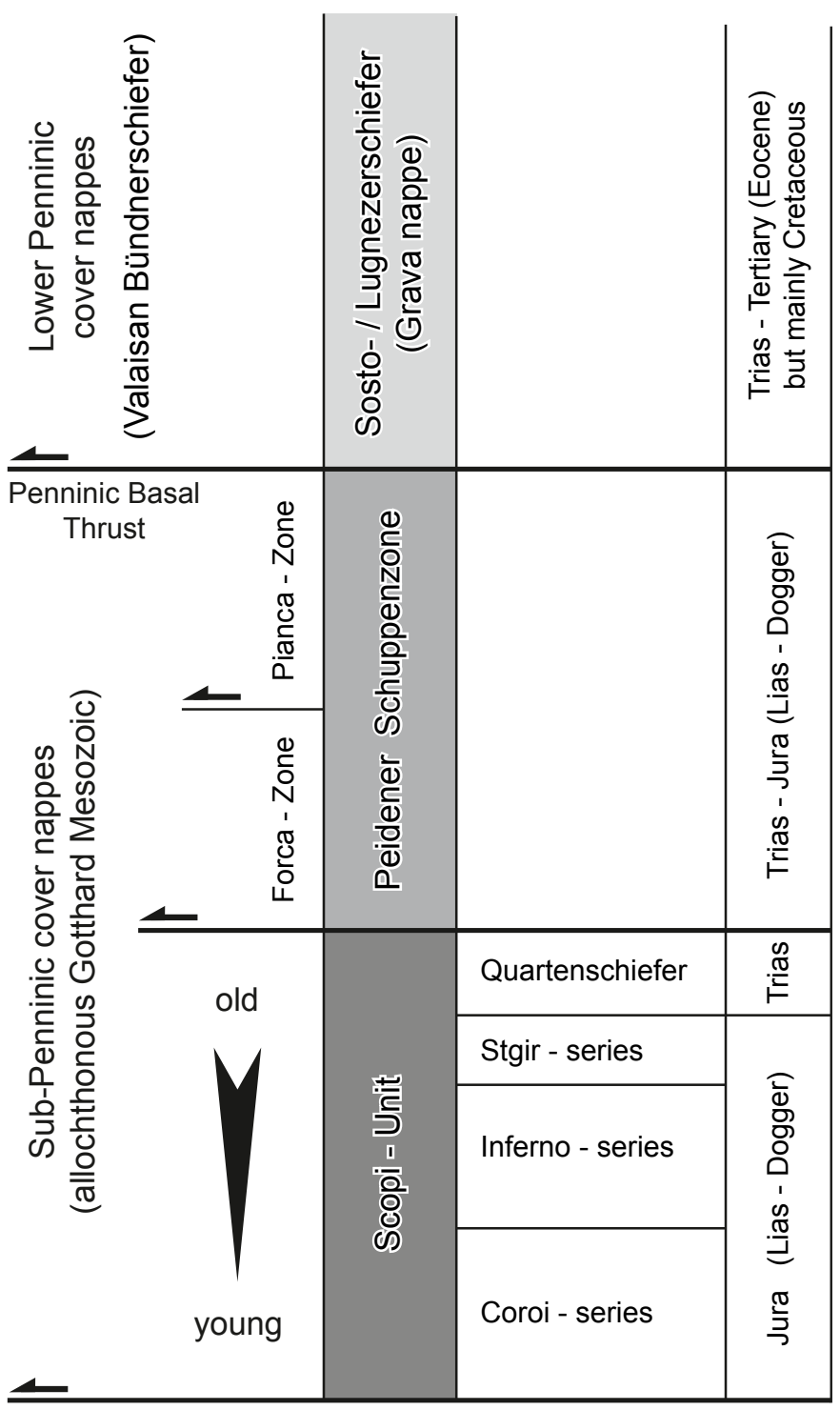

\section{Gotthard - "Massif" (Sub-Penninic basement) covered with autochthonous Lower Triassic}

Fig. 4. Tectono-stratigraphic scheme of the Sub-Penninic - Lower Penninic transition after Etter (1987).
The Adula nappe complex represents the highest structural unit within the Sub-Penninic nappe pile. It is generally overlain by the Lower Penninic Bündnerschiefer, but in the working area the contact between the Adula and overlying units is subvertical due to a late stage tectonic event. This nappe complex is not a coherent basement sliver but consists of several thin basement slices, separated from each other by Mesozoic slivers ("internal Mesozoic"; Löw 1987) and thin sediment-bearing mélange units, including meta-basalts and ultramafics, i.e. remnants of oceanic (presumably Valaisan) crust (Jenny et al. 1923; Trommsdorff 1990; Berger et al. 2005). Since it predominantly consists of continental basement rocks, we attribute it to the Sub-Penninic nappe complex (Schmid et al. 2004).

The Adula nappe complex is well known for its high-pressure metamorphism, showing a progressive increase from blueschist facies conditions $\left(1.2 \mathrm{GPa}\right.$ and $\left.500{ }^{\circ} \mathrm{C}\right)$ in the north to eclogite facies conditions $\left(800{ }^{\circ} \mathrm{C}\right.$ and $\left.>3 \mathrm{GPa}\right)$ in the south (Heinrich 1982; Heinrich 1986; Löw 1987; Meyre et al. 1997; Nimis \& Trommsdorff 2001; Nagel et al. 2002). Slightly different P-T conditions are given by Dale \& Holland (2003) who estimated $1.7 \mathrm{GPa}$ and $640{ }^{\circ} \mathrm{C}$ in the north and $2.5 \mathrm{GPa}$ and $750{ }^{\circ} \mathrm{C}$ in the south. High-pressure metamorphism is interpreted to be due to Eocene subduction of the distal European margin beneath the Adriatic continent (Becker 1993; Froitzheim et al. 1996; Schmid et al. 1996). A pressure-dominated upper blueschist facies event is also reported from the Simano nappe (1.2-1.4 GPa / $500{ }^{\circ} \mathrm{C}$; Rütti et al. 2005; Bousquet et al. 2008). Adula nappe complex and Simano nappe, together with the rest of the Sub-Penninic nappe stack from which so far no pressure-dominated metamorphism is reported, were overprinted by Barrow-type metamorphism reaching lower amphibolite facies conditions within the investigated area, i.e. $500-550{ }^{\circ} \mathrm{C}$ and 0.5-0.8 GPa (Engi et al. 1995; Todd \& Engi 1997; Frey \& Ferreiro Mählmann 1999).

\subsection{Sub-Penninic cover nappes and slices}

The sedimentary sequences found in these nappes and tectonic slices have strong affinities to non-metamorphic sequences of the southern Helvetic paleogeographic domain (Trümpy 1960). Hence, they are interpreted to represent the sedimentary cover of the most distal European margin (Froitzheim et al. 1996).

The Scopi Unit represents a lowermost cover nappe and is characterised by a coherent sedimentary stack in an overturned position. It tectonically overlays a thin veneer of Lower and Middle Triassic stratigraphic cover (Melser Sandstone Formation and Röti Dolomite Formation) of the Gotthard-"massif" basement nappe (Fig. 3; Baumer et al. 1961; Jung 1963; Baumer 1964; Frey 1967; Etter 1987). The Scopi Unit, together with the structurally higher Forca- and Pianca Zones (Fig. 4), forms what is often referred to as Gotthard-Mesozoic. These tectonic units are built up of sedimentary units detached along the evaporites of the Middle Triassic Röti Dolomite Formation from their former crystalline substratum that has to be looked for south of the Gotthard "massif" (Etter 1987). The Scopi Unit

S132 M. Wiederkehr et al. 

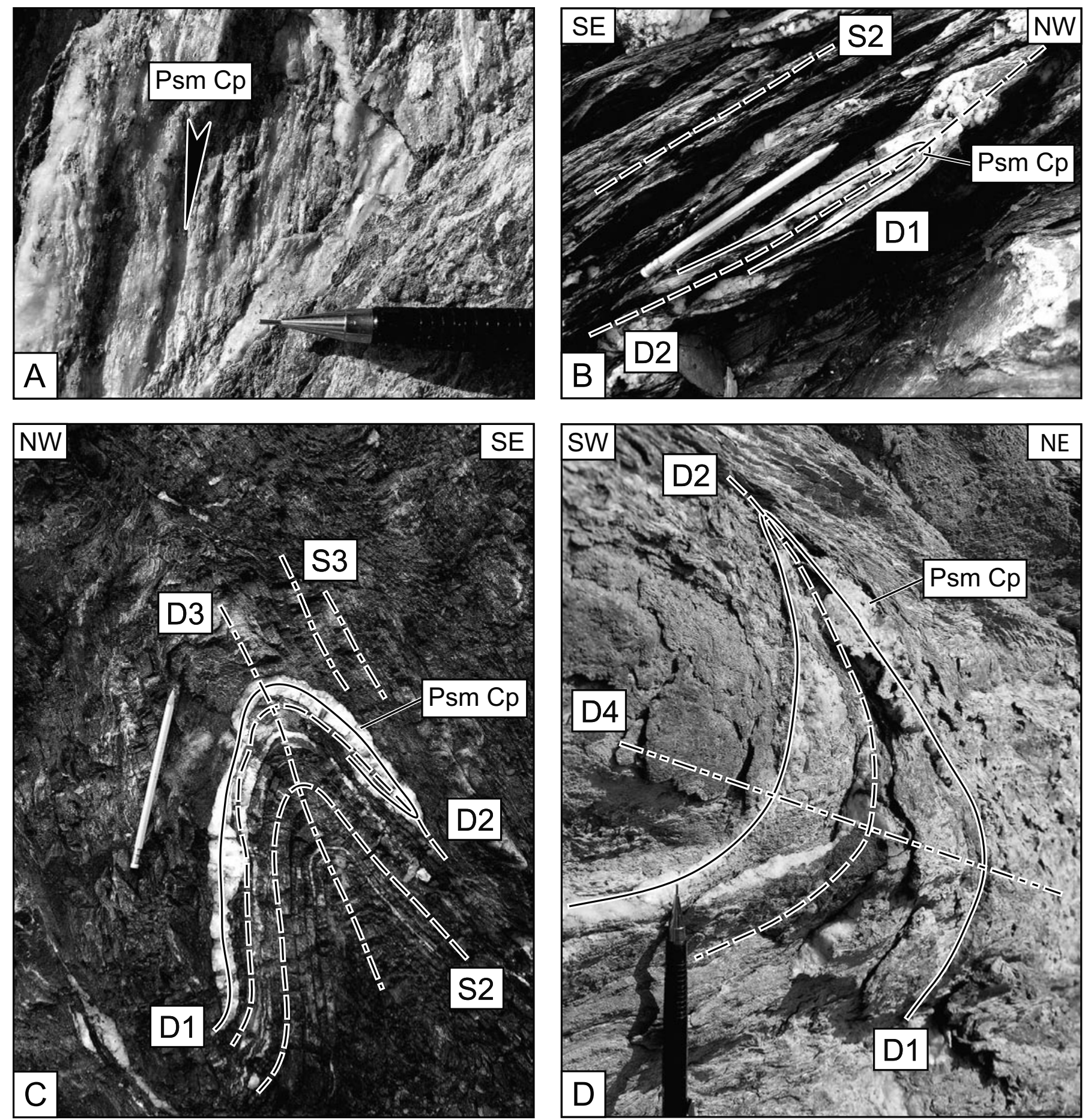

Fig. 5. Photographs of quartz-calcite veins representing pseudomorphs after Fe-Mg carpholite (Psm Cp). (A) Black arrow marks the orientation of characteristic fibrous growth of quartz, typical for pseudomorphs after Fe-Mg carpholite (Val Luzzone, 716'865/158'363,1780 m). (B) Pseudomorphs after carpholite (related to D1 deformation, Safien phase) are folded by D2 (Ferrera phase) and aligned parallel to the main foliation S2 in the fold limbs (Safiental, 739'942/160'530, 2350 m). (C) Pseudomorph after carpholite, refolded by D2 and D3 (Domleschg phase; Valsertal, 738'292/174' $969,1580 \mathrm{~m}$ ). Generally a new axial planar schistosity S3 ("spaced cleavage") evolved. In D3 fold hinges, S2 and S3 can easily be distinguished. (D) Pseudomorphs after carpholite, refolded by D2 (Ferrera phase) and D4 (Chièra phase; Val Luzzone, $\left.716^{\prime} 865 / 158^{\prime} 363,1780 \mathrm{~m}\right)$.

comprises a series of Late Triassic meta-pelites and meta-marls (Quartenschiefer), stratigraphically overlain by Jurassic sediments. The Lower to Middle Jurassic cover in Ultrahelvetic fa- cies consists of carbonates, calc-schists and meta-pelites that can be subdivided into three mappable formations, referred to as Stgir, Inferno and Coroi Series (Baumer et al. 1961). 
The Peidener Schuppenzone (imbricate zone), which tectonically overlies the Scopi Unit, consists of incoherent and chaotic sedimentary slices. This imbricate zone can be further subdivided into two major parts (Forca and Pianca Zones, Fig. 4; Frey 1967). We interpret the Peidener Schuppenzone as a sedimentary accretionary complex, which contains lithologies that are identical with those of the Scopi Unit, and they directly underlie the Lower Penninic cover nappes along the Penninic Basal Thrust (Figs. 3 \& 4). The southern and western parts of the Gotthard-Mesozoic, which underwent metamorphism under lower to middle amphibolite facies conditions $(0.5-0.8 \mathrm{GPa}$ and 500-550 ${ }^{\circ} \mathrm{C}$; Chadwick 1968; Frey 1969; Engi et al. 1995; Frey \& Ferreiro Mählmann 1999), represent a classical area of regional Barrow-type metamorphism (Frey 1969; Niggli 1970; Wenk 1970; Fox 1975; Frey 1978).

Another pile of Sub-Penninic cover nappes and slices, referred to as Piz Terri-Lunschania Unit, forms the core of a large isoclinal antiform (the so-called Lunschania antiform; Figs. 1 \& 3), located in front of the Adula nappe complex. The Piz TerriLunschania Unit is considered as Sub-Penninic because it is structurally in the footwall of the folded Penninic Basal Thrust. The Piz Terri-Lunschania Unit originally represents the sedimentary cover of the basement of the Soja nappe and hence roots below the Adula nappe complex, i.e. also below the Penninic Basal Thrust (Figs. 1 \& 3; Probst 1980). The structurally lower cover nappe, the so-called Piz Terri Gipfelzone Unit, consists of thick and rather homogenous black and sandy calcschists, which often resemble the Bündnerschiefer of the Lower Penninic units. The Piz Terri Gipfelzone Unit was overlain by heterogeneous sedimentary slices consisting of dolomitic marbles, meta-pelites, black shales, quartzitic micaschists and layered shaly-sandy calcareous sediments (Piz Terri Schuppenzone). These are now found along both limbs of the Lunschania antiform. They have been interpreted as tectonic imbricates (Kupferschmid 1977; Probst 1980; Uhr unpubl.) and they are in direct tectonic contact with the Lower Penninic Grava nappe. The stratigraphy of the sediments of the Piz Terri-Lunschania Unit is ill defined due to intense deformation and scarcity of fossils. A Triassic to Middle Jurassic age is inferred, based on lithological criteria and fossil record (Kupferschmid 1977; Probst 1980). So far little was known regarding the metamorphic overprint of this zone.

\subsection{Lower Penninic cover nappes (Valais Bündnerschiefer)}

In the eastern part of the study area (Fig. 1) the lower Penninic cover nappes represent an up to $15 \mathrm{~km}$ thick volume of limestones, shales, marls and calc-schists originally deposited in the Valaisan Ocean. This thickness diminishes towards the west and around Olivone only very reduced series are conserved (Figs. 1, $2 \&$ 3). Further to the east (Grisons area) the Lower Penninic Bündnerschiefer can be subdivided into, from top to bottom, the Tomül and Grava nappes, consisting of a Cretaceous- to Eocene-age sedimentary sequence (Nänny 1948; Steinmann 1994a, b), and three imbricate zones: Aul-Unit,
Upper and Lower Valser Schuppenzone (Steinmann 1994a, b). In contrast to the Sub-Penninic cover nappes all these units are rooted above the Adula nappe complex (Probst 1980; Steinmann 1994a, b).

Only the Grava nappe reaches the Val Luzzone and northern Valle di Blenio in the central and western parts of the working area, respectively, where the base of this cover nappe (here referred to as Sosto and Lugnez schists; Probst 1980) forms the Penninic Basal Thrust (Fig. 4). In the east,i.e. in the area around Vals, Jurassic-age (dating based on stratigraphic criteria; Steinmann 1994a) mafic and ultramafic rocks are associated with meta-sediments, both forming the Aul Unit (Figs. 1 \& 3). In some places the meta-basalts preserve pillow structures (Steinmann 1994a, b) and are locally associated with serpentinites (Piz Aul; Nabholz 1945). This indicates that parts of the Valais Bündnerschiefer were deposited on oceanic crust (Steinmann 1994a, b).

The metamorphism of the Valais Bündnerschiefer units is characterised by the occurrence of Fe-Mg carpholite (Goffé \& Oberhänsli 1992; Bousquet et al. 2002), i.e. a typical index mineral for HP/LT conditions in meta-sediments (Goffé \& Chopin 1986; Bousquet et al. 2008). Interestingly, Fe-Mg carpholite is described from both sides of the Lepontine dome, documenting blueschist facies conditions for the Petit St. Bernard area in the west (1.7 GPa, 350-400 ${ }^{\circ} \mathrm{C}$; Goffé \& Bousquet 1997) as well as in the Grisons including the Engadine window in the east (1.2-1.3 GPa, 350-400 ${ }^{\circ} \mathrm{C}$; Bousquet et al. 1998). Both these high-pressure occurrences follow a northern suture zone between Briançonnais micro-continent and distal European margin that is formed by tectonic units attributed to the former Valais Ocean (Bousquet et al. 2002).

\section{Structural evolution}

In the following, we will first describe the four major deformation phases observed in the studied area. These are documented by clearly observable overprinting patterns. We will then correlate structural and metamorphic evolution in a second step and finally discuss and compare the results obtained in the working area with the large-scale geological context concerning the geodynamic evolution of the Alps.

\subsection{First deformation phase (D1)}

The first phase of deformation led to the formation of widespread, often carpholite-bearing calcite, quartz and quartzcalcite veins mainly found in calcareous schists in both the Sub-Penninic and Lower Penninic meta-sediments (Voll 1976). These veins represent oblique fibrous veins that opened in a transtensive manner by re-precipitation from hydrous solutions, which led to the growth of the fibres (Weh \& Froitzheim 2001). The veins typically resemble fibrous carpholite pseudomorphs described in the literature (Fig. 5a; Goffé \& Chopin 1986; Agard et al. 2001; Rimmelé et al. 2003; Trotet et al. 2006). Such fibres of Fe-Mg carpholite, indicative of HP/LT metamor-

S134 M. Wiederkehr et al. 
phic conditions, are typically found only within fibrous segregations and rarely in the surrounding rock matrix. Since no major folding structures formed during D1 and since the surrounding rock matrix is occasionally found virtually undeformed (Fig. 6), we infer semi-ductile behaviour during D1, largely characterised by solution and re-precipitation processes.

Since the HP/LT mineral assemblage carpholite - chlorite - phengite - quartz \pm chloritoid is found in meta-sediments of both Lower Penninic (Grava and Tomül nappes) and Sub-Penninic units (Peidener Schuppenzone), the tectonic contact between the most distal European margin and the Valais Ocean, the Penninic Basal Thrust, must have already formed during D1. Although the more external Sub-Penninic units may also have been affected by D1, these units lack carpholite-bearing veins.

\subsection{Second deformation phase (D2)}

This deformation post-dates D1, since the carpholite-bearing quartz-calcite veins are isoclinally folded and overprinted by the S2 penetrative main and axial planar schistosity (Fig. 5b). Due to polyphase overprinting during later phases of folding, the orientations of D2 structures, such as fold axes and fold axial planes, show a large spread in orientation. The D2 schistosity completely transposes bedding, and possibly, relics of an earlier D1 schistosity that may have existed in pelitic lithologies.
This penetrative, main D2 foliation is largely formed by phengite and chlorite, which indicates greenschist facies conditions during D2 deformation. Hence D2 was associated with early exhumation of the blueschist-facies rocks. In analogy with the findings of Bucher \& Bousquet (2007) and Bucher et al. $(2003,2004)$ in the Western Alps, we interpret this main phase of nappe stacking to be associated with the exhumation of highpressure rocks. Thereby relatively more internal and higherpressure units were thrust onto relatively more external and lower-pressure units.

\subsection{Third deformation phase (D3)}

D3 deformation produces tight mega-folds such as the Lunschania antiform (Figs. $1 \& 3$ ), as well as folds observable at the mesoscopic and microscopic scale. A second strong axial planar cleavage S3 is associated with D3 folding. However, the distinction between S2 and S3 can only be made in D3 fold hinges where S3 represents a spaced cleavage (Fig. 5c), while S3 completely transposes $\mathrm{S} 2$ in $\mathrm{F} 3$ fold limbs. In most places the main foliation represents a composite $\mathrm{S} 2 / \mathrm{S} 3$ schistosity.

Due to D4 overprint in the western part of the working area, the D3 fold axes and fold axial planes often show variable orientations. Further east (east of Vrin), D3 fold axes strike SW-NE, plunging gently either NE or SW; fold axial planes

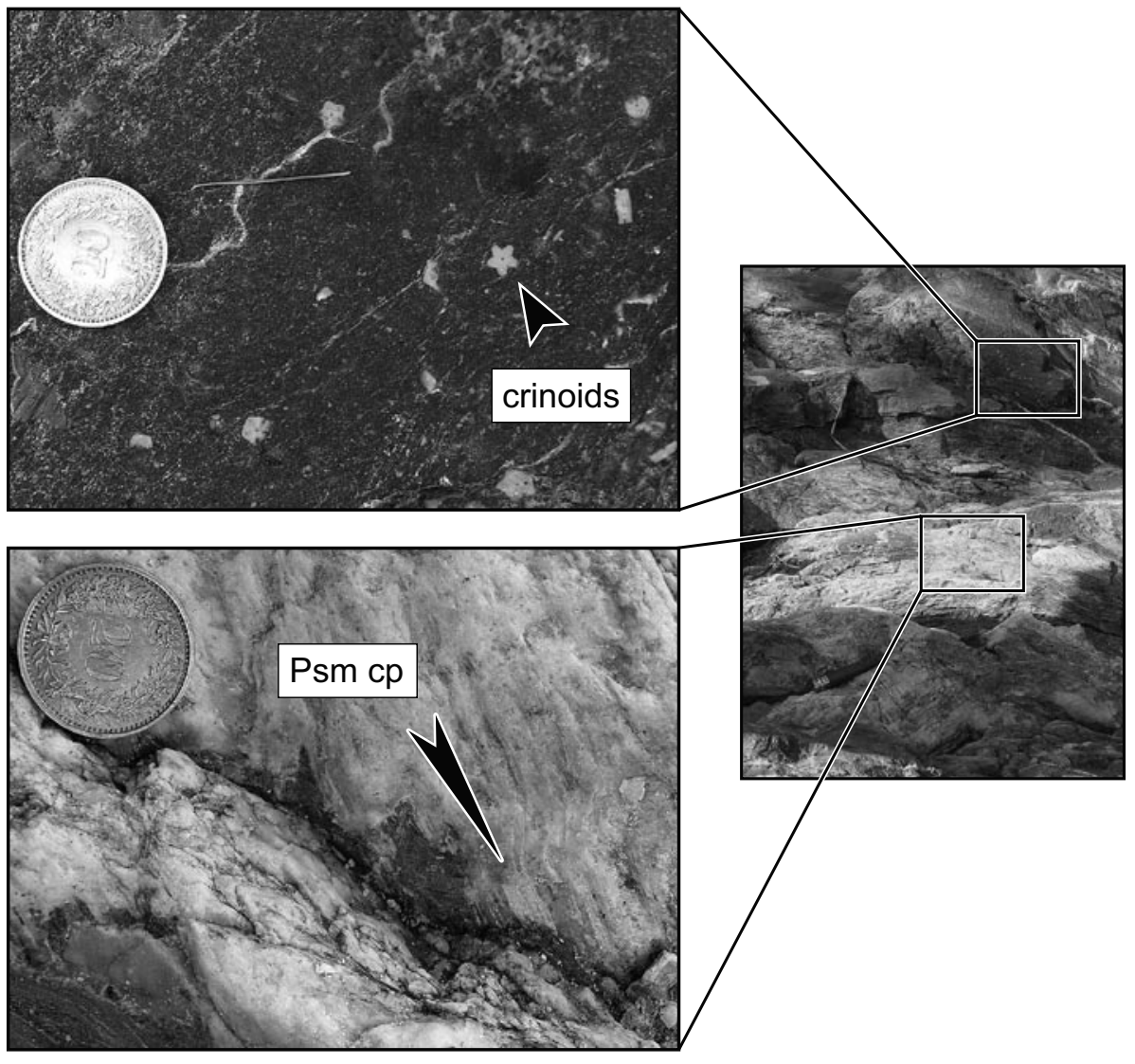

Fig. 6. Photograph showing pseudomorphs after carpholite, together with almost undeformed crinoids in the Forca slice of the Peidener Schuppenzone (Sub-Penninic sediments; Val Luzzone, $717^{\prime} 364 / 160 ' 358,1860 \mathrm{~m}$ ). The black arrow in the lower picture is oriented parallel to the quartz fibres.

From subduction to collision S135 
steeply dip SE to SSE. There a crenulation is often associated with D3 deformation, the crenulation lineation being oriented parallel to D3 fold axes.

\subsection{Fourth deformation phase (D4)}

D4 deformation is only observed in the SW part of the investigated area (Figs. 1 \& 2), strain intensity rapidly decreasing towards the NE. D4 deformation sets in east of Piz Terri while intensive folding affects the area around Pizzo Molare and between the southern Lukmanier area and Olivone (Figs. 2 \& 3). D4 folds are open, often without an axial planar schistosity. They refold the S2/S3 composite schistosity (Fig. 5d). Typically, D4 folds have an undulating and wavy appearance, producing a staircase-like set of syn- and antiforms on the macroscopic scale, striking E-W to ESE-WNW (Figs. 2 \& 3).

However, a new axial plane schistosity S4 locally evolves in fold hinges of tighter D4 folds and overprints the S2/S3 composite foliation. In such cases this new $\mathrm{S} 4$ foliation represents a pressure solution cleavage producing microlithons within which overprinting of the S2/S3 composite foliation is well preserved on a microscopic scale.

The E-W striking D4 fold axes dip moderately $\left(20-40^{\circ}\right)$ towards the $\mathrm{E}$ in most of the working area. Only around Pizzo Molare and south of Olivone the fold axes dip towards SEESE. It is important to note that the D4 fold axial planes generally plunge with $30-50^{\circ}$ to the NE. Hence the D4 folds represent back-folds, which are typical for the so-called Northern Steep Belt at the northern rim of the Lepontine dome (Milnes 1974).

\section{New data regarding the metamorphic evolution of the area}

A remarkable metamorphic field gradient is deduced for the investigated area, ranging from low-temperature $\left(\leq 400{ }^{\circ} \mathrm{C}\right)$ blueschist facies metamorphism in the east all the way to classical Barrow-type amphibolite facies overprint (up to $570{ }^{\circ} \mathrm{C}$ ) further west (Figs. $1 \& 2$ ). Moreover, for the first time we are able to distinguish between two separate metamorphic stages in the Sub-Penninic and Lower Penninic meta-sedimentary units in the north-eastern Lepontine: an earlier HP/LT event is followed by a MP/MT Barrovian event.

\subsection{Spatial distribution of index minerals and mineral parageneses}

The HP/LT event is documented by the mineral assemblage Fe-Mg carpholite - chlorite - phengite - quartz \pm chloritoid, relics of which are widespread in the Lower Penninic Grava and Tomül nappes east of the Lepontine dome (Bousquet et al. 2002). Remnants of this assemblage, notably relics and/or pseudomorphs after Fe-Mg carpholite, are even found in the westernmost exposures of the Grava nappe as far as Pizzo Molare, hence in an area well inside the thermally overprinted realm of the Lepontine dome (Fig. 2). Relics and pseudomorphs af- ter Fe-Mg carpholite were also found further north within the imbricated Sub-Penninic Peidener Schuppenzone. There, such pseudomorphs occur as fibrous quartz-calcite veins, which crosscut meta-sedimentary units containing almost undeformed crinoids (Fig. 6). This documents for the first time that HP/LT metamorphic conditions also affected Ultrahelvetic meta-sediments, derived from the former distal European margin. This clearly points to the existence of a second and more northerly-located Alpine subduction zone with respect to the Upper Penninic Suture Zone, as pointed out by several authors (e.g. Stampfli 1993; Stampfli et al. 1998; Bousquet et al. 2002; Nagel et al. 2002; Froitzheim et al. 2003; Pleuger et al. 2003).

The classical Barrow-type amphibolite facies overprint is associated with a pronounced metamorphic field gradient. Towards the south-west a gradual succession of newly growing minerals indicates an increase in temperature from greenschist to lower/middle amphibolite facies conditions. This is deduced from the progressive appearance of chloritoid, zoisite, plagioclase, titanite, biotite, garnet, staurolite, kyanite and finally amphibole (Fig. 2). Furthermore, in the south-western part of the working area around Pizzo Molare and between Olivone and the southern Lukmanier area, where pseudomorphs of $\mathrm{Fe}-\mathrm{Mg}$ carpholite are also present, the mineral assemblage staurolite - kyanite - garnet - plagioclase - biotite - phengite \pm amphibole clearly indicates a thermal overprint under lower to middle amphibolite facies conditions (Chadwick 1968; Frey 1969; Thakur 1971; Engi et al. 1995). Towards the north-east the mineral parageneses chloritoid - phengite - chlorite - quartz and zoisite/clinozoisite - chlorite - phengite - quartz - calcite/ dolomite indicate greenschist facies conditions related to the same Barrow-type event (Jung 1963; Frey 1967; Frey \& Ferreiro Mählmann 1999). In contrast to the earlier HP/LT event, restricted to the Grava nappe and the Peidener Schuppenzone, the Barrow-type overprint affected all the units of the working area (Fig. 2). In the following the new data concerning the two metamorphic events will be described in more detail.

\subsection{Data on the earlier HP/LT metamorphic event}

Occurrences or relics of the HP/LT mineral assemblage Fe-Mg carpholite - chlorite - phengite - quartz \pm chloritoid are only found within quartz- and calcite-bearing veins or segregations. Fibrous mesoscopic appearance and characteristic light green silvery colour of such veins or segregations resemble the typical Fe-Mg carpholite pseudomorphs described in the literature (Fig. 5a; Goffé \& Chopin 1986; Goffé et al. 1989; Fournier et al. 1991). It is important to emphasise that in the study area $\mathrm{Fe}-\mathrm{Mg}$ carpholite was never found in the matrix of the rocks; it exclusively occurs within veins and/or segregations. This, together with the fact that undeformed crinoids are found in the neighbouring rocks next to these veins (Fig. 6), indicates that carpholite growth occurred in the context of veining and dehydration, i.e. probably during subduction.

However, Fe-Mg carpholite is only preserved in the form of microscopic-scale relics (Fig. 7a) within quartz-calcite segrega-

S136 M. Wiederkehr et al. 

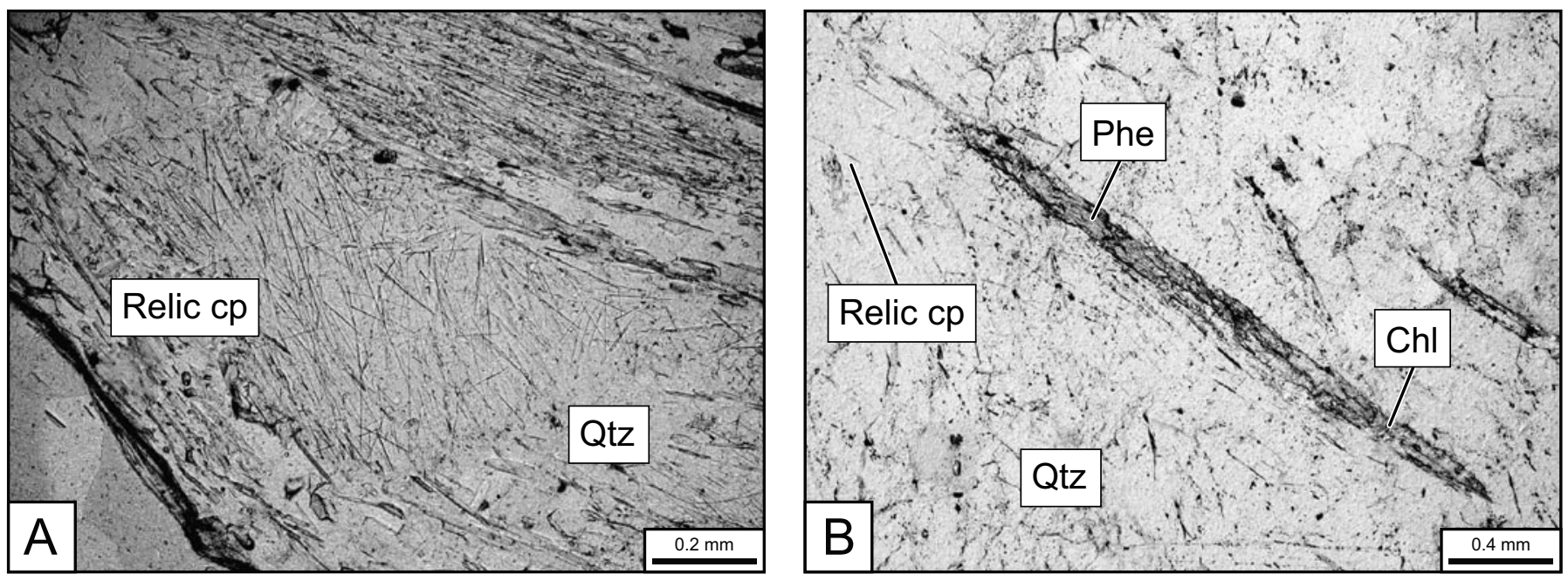

Fig. 7. Photomicrographs of thin sections showing mineral assemblages related to the HP/LT event, preserved as inclusions in quartz-calcite fibrous veins generally interpreted as pseudomorphs after Fe-Mg carpholite. (A) Hair-like fibres represent relics of Fe-Mg carpholite (cp) as inclusions in quartz (SW of Vrin, 723'990/166'197, 1890 m). (B) Phengite, quartz and chlorite define a needle-shaped pseudomorph after carpholite. Still preserved relics of carpholite can be found as hair-like fibres (Val Luzzone, 720'938/162'275, $2600 \mathrm{~m}$ ).

tions or veins that represent macroscopically visible pseudomorphs after large former Fe-Mg carpholite crystals (Fig. 5a). No Fe-Mg carpholite crystals preserved on a macroscopic scale, such as described from the Engadine window (Bousquet et al. 1998), were found. The macroscopic pseudomorphs are mainly built up by fibrous quartz (Fig. 5a). Its shimmering silver-green lustre is due to a thin layer of chlorite and phengite. In thin section, fibrous quartz is full of inclusions of chlorite, phengite and paragonite. This assemblage often forms needle-shaped pseudomorphs after Fe-Mg-carpholite (Fig. 7b). Rarely chloritoid has also been found as inclusions in such fibrous quartz-calcite veins.

In order to estimate peak-pressure conditions, the chemical compositions of HP/LT minerals were determined by wavelength-dispersive X-ray analysis (WDS) using a CAMECA SX-100 electron microprobe at the GeoForschungsZentrum (GFZ) Potsdam. The analytical conditions included an acceleration voltage of $15 \mathrm{kV}$, a beam current of $20 \mathrm{nA}$ and beam diameters of 1-10 $\mu \mathrm{m}$; PAP corrections were applied. Natural and synthetic minerals were used as standards. Peak counting times were 10-20 s for major and 20-40 s for minor elements; backgrounds were counted for 5-20 s.

Relics of Fe-Mg carpholite are hair-thin micro-fibres (10 to $100 \mu \mathrm{m}$ long, 0.5 to $10 \mu \mathrm{m}$ wide) embedded in quartz (Fig. 7a) documented by Raman spectroscopy and microprobe analysis. In order to avoid the effect of contamination by the surrounding quartz, the chemical composition of $\mathrm{Fe}-\mathrm{Mg}$ carpholite $\left[(\mathrm{Mg}, \mathrm{Fe}, \mathrm{Mn}) \mathrm{Al}_{2} \mathrm{Si}_{2} \mathrm{O}_{6}(\mathrm{OH}, \mathrm{F})_{4}\right]$ was calculated on the basis of a fixed atomic number of cations (Goffé \& Oberhänsli 1992). The value of $X_{\mathrm{Mg}}[\mathrm{Mg} /(\mathrm{Mg}+\mathrm{Fe}+\mathrm{Mn})]$ is rather constant, ranging from 0.44 to 0.55 (mean value 0.49) in the Penninic Bündnerschiefer of the Grava nappe, and from 0.39 to 0.57 (mean value 0.49 ) in the Sub-Penninic Peidener Schuppenzone (Table 1).
Generally the fluorine content is very low and varies from 0.0 to $0.99 \mathrm{wt} \%$.

White mica is also found as inclusions in quartz grains. Both phengite and paragonite are present and associated with chlorite and quartz. They form also part of the pseudomorphs after Fe-Mg carpholite (Fig. 7b). There, phengite and paragonite occur as fine-grained flakes without any shape preferred orientation. The $\mathrm{Si}^{4+}$ content, reflecting the phengitic substitution in white mica replacing Fe-Mg carpholite, ranges from 3.24 in the Valais Bündnerschiefer to 3.12 p.f.u in the Sub-Penninic Peidener Schuppenzone (Table 1).

Chlorite occurs as randomly arranged grains, together with white mica and quartz, but also within pseudomorphs after Fe-Mg carpholite (Fig. 7b). In the Valais Bündnerschiefer the Tschermak substitution in chlorites is around $2.57-2.70(\mathrm{Si}$ p.f.u.), $\mathrm{X}_{\mathrm{Mg}}$ ranging from 0.43 to 0.60 . In the Sub-Penninic sediments between 2.52 and 2.61 Si p.f.u. and $\mathrm{X}_{\mathrm{Mg}}$ from 0.44 to 0.48 were measured (Table 1).

Only in a few cases chloritoid was found inside quartz-calcite segregations containing relics of Fe-Mg carpholite. Such chloritoid forms small prisms with $\mathrm{X}_{\mathrm{Mg}}$-values varying between 0.12 in the Valais Bündnerschiefer and 0.20 in the Sub-Penninic meta-sediments (Table 1). This chloritoid is interpreted to have formed during prograde metamorphism by reaction from Fe-Mg carpholite, as shown by Vidal et al. (1992); i.e. during the high-pressure stage rather than during a greenschist facies event (see discussion in Oberhänsli et al. 2003).

\subsection{Data on the subsequent temperature-dominated event}

While remnants of the HP/LT metamorphic event are restricted to quartz-calcite segregations within the Lower Penninic Bündnerschiefer and the Sub-Penninic Peidener Schuppenzone, the 
Table 1. Representative microprobe mineral analyses of HP/LT assemblages found as inclusions in quartz-calcite veins, interpreted as pseudomorphs after carpholite of Valaisan (Grava nappe) and Sub-Penninic (Peidener Schuppenzone) meta-sedimentary units given in weight-percents. The locations of the samples are shown in Figure 2. The deviations from $100 \%$ are mainly due to the $\mathrm{OH}$-content not detected by microprobe analyses. The sums of Fe-Mg carpholite analyses have been corrected for fluorine content; the values given under "Total corr." take into account that fluorine occupies an oxygen site. The structural formulae for carpholite were calculated by using 5 cations for Si and 3 cations for Al, Fe, Mn and Mg, following Goffé \& Oberhänsli (1992). For chlorite we used 14 oxygens, for white mica 11 and for chloritoid 12, following Chopin et al. (1992). The following abbreviations have been used: $\mathrm{Cp}=\mathrm{Fe}-\mathrm{Mg}$ carpholite, Ctd = chloritoid, $\mathrm{Chl}=$ chlorite, $\mathrm{Phe}=$ phengite, $\mathrm{Pg}=$ paragonite.

\begin{tabular}{|c|c|c|c|c|c|c|c|c|c|c|c|c|c|c|c|}
\hline \multirow{3}{*}{$\begin{array}{l}\text { Unit } \\
\text { Sample } \\
\text { Minerals } \\
\text { Analysis }(w t-\%)\end{array}$} & \multicolumn{8}{|c|}{ Valaisan Bündnerschiefer (Grava nappe) } & \multicolumn{7}{|c|}{ Sub-Penninic sediments (Peidener Schuppenzone) } \\
\hline & \multicolumn{5}{|c|}{ LUZ 0432} & \multicolumn{3}{|c|}{ LUZ 0416} & \multicolumn{4}{|c|}{ LUZ 047} & \multicolumn{3}{|c|}{ LAR 061} \\
\hline & $\begin{array}{c}\text { Cp } \\
C p 828\end{array}$ & $\begin{array}{c}\text { Ctd } \\
\text { Ctd215 }\end{array}$ & $\begin{array}{c}\text { Chl } \\
\text { Chl219 }\end{array}$ & $\begin{array}{c}\text { Phe } \\
\text { Phe221 }\end{array}$ & $\begin{array}{c}\text { Pg } \\
P g 220\end{array}$ & $\begin{array}{c}\mathbf{C p} \\
C p 849\end{array}$ & $\begin{array}{c}\text { Chl } \\
\text { Chl207 }\end{array}$ & $\begin{array}{c}\text { Phe } \\
\text { Phe224 }\end{array}$ & $\begin{array}{c}\text { Cp } \\
C p 9 B\end{array}$ & $\begin{array}{c}\text { Ctd } \\
\text { Ctd16 }\end{array}$ & $\begin{array}{l}\text { Chl } \\
\text { Chl5 }\end{array}$ & $\begin{array}{l}\text { Phe } \\
\text { Phe1 }\end{array}$ & $\begin{array}{c}\text { Cp } \\
C p 12\end{array}$ & $\begin{array}{l}\text { Chl } \\
\text { Chl4 }\end{array}$ & $\begin{array}{c}\text { Phe } \\
\text { Phe12 }\end{array}$ \\
\hline $\mathrm{SiO}_{2}$ & 37.40 & 24.46 & 25.36 & 49.46 & 48.43 & 37.63 & 25.30 & 48.60 & 37.85 & 25.32 & 23.17 & 47.18 & 38.00 & 23.63 & 47.20 \\
\hline $\mathrm{Cr}_{2} \mathrm{O}_{3}$ & 0.03 & 0.00 & 0.00 & 0.00 & 0.00 & 0.00 & 0.00 & 0.00 & 0.00 & 0.00 & 0.00 & 0.00 & 0.03 & 0.00 & 0.00 \\
\hline $\mathrm{FeO}$ & 11.44 & 25.42 & 27.37 & 1.34 & 0.20 & 12.64 & 26.51 & 1.24 & 10.92 & 22.55 & 27.27 & 0.81 & 13.90 & 27.05 & 0.49 \\
\hline $\mathrm{MnO}$ & 0.25 & 0.06 & 0.02 & 0.00 & 0.01 & 0.30 & 0.05 & 0.00 & 0.06 & 0.27 & 0.01 & 0.00 & 0.03 & 0.08 & 0.01 \\
\hline $\mathrm{MgO}$ & 6.32 & 1.85 & 12.73 & 1.39 & 0.12 & 5.68 & 13.39 & 1.20 & 6.27 & 2.83 & 11.98 & 0.85 & 6.49 & 12.62 & 0.62 \\
\hline $\mathrm{CaO}$ & 0.00 & 0.00 & 0.00 & 0.00 & 0.07 & 0.02 & 0.01 & 0.00 & 0.01 & 0.00 & 0.00 & 0.00 & 0.00 & 0.03 & 0.02 \\
\hline $\mathrm{F}$ & 0.65 & 0.00 & 0.00 & 0.00 & 0.00 & 0.77 & 0.00 & 0.00 & 0.49 & 0.00 & 0.00 & 0.00 & 0.00 & 0.00 & 0.00 \\
\hline Total & 87.43 & 91.15 & 88.48 & 95.39 & 97.54 & 88.64 & 87.72 & 95.16 & 88.03 & 89.78 & 86.07 & 94.50 & 88.76 & 86.08 & 94.19 \\
\hline Total corr. & 87.17 & 91.15 & 88.48 & 95.39 & 97.54 & 88.32 & 87.72 & 95.16 & 87.83 & 89.78 & 86.07 & 94.50 & 88.76 & 86.08 & 94.19 \\
\hline $\mathrm{Si}$ & 2.00 & 2.05 & 2.67 & 3.24 & 3.02 & 2.00 & 2.67 & 3.20 & 2.00 & 2.13 & 2.52 & 3.12 & 2.00 & 2.57 & 3.12 \\
\hline $\mathrm{Ti}$ & 0.01 & 0.00 & 0.00 & 0.01 & 0.00 & 0.01 & 0.00 & 0.01 & 0.00 & 0.00 & 0.00 & 0.01 & 0.01 & 0.00 & 0.00 \\
\hline $\mathrm{Al}$ & 1.96 & 3.90 & 2.84 & 2.59 & 2.96 & 1.96 & 2.79 & 2.64 & 2.02 & 3.85 & 3.02 & 2.80 & 1.86 & 2.90 & 2.83 \\
\hline $\mathrm{Cr}$ & 0.00 & 0.00 & 0.00 & 0.00 & 0.00 & 0.00 & 0.00 & 0.00 & 0.00 & 0.00 & 0.00 & 0.00 & 0.00 & 0.00 & 0.00 \\
\hline $\mathrm{Fe}^{3+}$ & 0.04 & 0.05 & - & - & - & 0.04 & - & - & 0.00 & 0.02 & - & - & 0.14 & - & - \\
\hline $\mathrm{Fe}^{2+}$ & 0.47 & 1.74 & 2.41 & 0.07 & 0.01 & 0.52 & 2.34 & 0.07 & 0.52 & 1.56 & 2.48 & 0.04 & 0.47 & 2.46 & 0.03 \\
\hline $\mathrm{Mn}$ & 0.01 & 0.00 & 0.00 & 0.00 & 0.00 & 0.01 & 0.00 & 0.00 & 0.00 & 0.02 & 0.00 & 0.00 & 0.00 & 0.01 & 0.00 \\
\hline $\mathrm{XMg}$ & 0.51 & 0.12 & 0.45 & & & 0.46 & 0.47 & & 0.49 & 0.18 & 0.44 & & 0.52 & 0.45 & \\
\hline
\end{tabular}

temperature-dominated Barrovian event affected all tectonic units (Fig. 2). From north-east to south-west, i.e. from greenschist to lower/middle amphibolite facies overprint, the following mineral assemblages are described.

Greenschist facies: Chloritoid growing during the second metamorphic event and at the expense of pyrophyllite and chlorite can be texturally distinguished from that produced by the breakdown of Fe-Mg carpholite. Whereas the scarce occurrences of HP/LT chloritoid are restricted to microscopic-scale inclusions in quartz-calcite veins containing preserved relics of Fe-Mg carpholite, LP/LT chloritoid occurs in the rock-matrix as idiomorphic rosettes, bundles and prisms, together with quartz, white mica and chlorite. It is common in shaly formations of the Stgir and Coroi Series of the Gotthard-Mesozoic (Scopi Unit and Peidener Schuppenzone), as well as in quartzitic formations of the Piz Terri-Lunschania Unit (Jung 1963; Frey 1967; Probst 1980; Fig. 2). The mineral assemblage chloritoid-white mica-chlorite-quartz is typical for the Sub-Penninic sedimentary units in the study area. The overlying Lower Penninic 
Bündnerschiefer are characterised by the mineral assemblage phengite - chlorite - quartz - calcite/dolomite. However, chloritoid has not been identified with the exception of rare occurrences in quartz-calcite veins interpreted as relics of the HP/LT stage, as discussed above. The lack of chloritoid is most probably due to the bulk rock composition in the Lower Penninic Bündnerschiefer, which is generally Ca-rich and Al-poor.

Upper greenschist facies: In the Val Luzzone area, the mineralogical composition of the Lower Penninic Bündnerschiefer changes dramatically (Fig. 2). Newly formed zoisite/clinozoisite, plagioclase and titanite indicate an increase in temperature. This is corroborated by the mineral assemblage plagioclase - zoisite/clinozoisite - titanite - phengite - chlorite - quartz - calcite/ dolomite found in marly or calcareous schists of the Grava nappe. When entering the upper greenschist facies stability field, zoisite/clinozoisite is the first newly grown mineral observed. Based on mineral shape and composition the following two zoisite/clinozoisite types are found within the same rocks (Frank 1983; Kuhn et al. 2005): (1) Fine-grained, needle-shaped, prismatic zoisite/clinozoisite, enriched in $\mathrm{Fe}^{3+}$ relative to $\mathrm{Al}^{\mathrm{VI}}$ with an $\mathrm{X}_{\mathrm{Ep}}\left[\mathrm{Fe}^{3+} /\left(\mathrm{Fe}^{3+}+\mathrm{Al}-2\right)\right]$ of $0.15-0.20$. Some grains show distinct compositional zoning, with cores being richer in $\mathrm{Fe}^{3+}$ compared to the rims $\left(\mathrm{X}_{\mathrm{Ep}}\right.$ core $=0.63$; rim $\left.=0.20\right)$, and, $(2)$ an almost pure Al-end member with $\mathrm{X}_{\mathrm{Ep}}$ of $0.03-0.05$ forming relatively large crystals arranged as rosettes and sheaves, up to $5 \mathrm{~cm}$ in diameter (Fig. 8a). Plagioclase forming black plates up to several $\mathrm{mm}$ in size is present as oligoclase, with an An-content varying between 0.19 and 0.36. Titanite, another characteristic mineral of this zone, forms bi-pyramidal crystals up to $3 \mathrm{~mm}$ in size.

Upper greenschist to amphibolite facies transition: Biotite first appears west of the retaining wall of Lago di Luzzone within the Lower Penninic Bündnerschiefer (Fig. 2). This site roughly coincides with the north-eastern border of the Lepontine thermal dome as mapped by Spicher (1980). The assemblage biotite - plagioclase - zoisite/clinozoisite - titanite - phengite - quartz - calcite/dolomite \pm chlorite is characteristic for the upper greenschist to amphibolite facies transition. The Jurassic sediments of the Sub-Penninic units (Stgir Series of the Peidener Schuppenzone) are less calcareous and more pelitic than the overlying Lower Penninic Bündnerschiefer (Fox 1975). This difference in chemical composition led to the formation of garnet in the Stgir Series, which is absent in the Lower Penninic Bündnerschiefer in the study area. Garnet first appears north of Olivone (northern Valle di Blenio; Figs. 1 \& 2) within the assemblage garnet - biotite - plagioclase - phengite - quartz \pm chlorite \pm zoisite/clinozoisite. The co-existence of garnet and biotite is typical for the upper greenschist to amphibolite facies transition (Bucher \& Frey 2002). The almandine-rich garnets $\left(\mathrm{Alm}_{0.71} \operatorname{Prp}_{0.06} \mathrm{Grs}_{0.21} \mathrm{Sps}_{0.02}\right)$ are chemically more or less unzoned and form crystals up to $1 \mathrm{~cm}$ in size.

Lower to middle amphibolite facies: Kyanite, staurolite and amphibole appear in addition further SW (Valle di Blenio,
Pizzo Molare, and south of the Lukmanier pass; Figs. 1 \& 2). Pelitic meta-sediments of the Sub-Penninic units are characterised by the mineral assemblage staurolite - kyanite - garnet - biotite - plagioclase - phengite - quartz (Baumer 1964; Chadwick 1968; Frey 1969; Thakur 1971; Fox 1975; Probst 1980), typically indicating lower to middle amphibolite facies conditions. In general, garnet is almandine-rich and shows a normal zoning pattern with increasing $\mathrm{Mg}$ - and decreasing Mn-content from core to rim. Garnets from the Pizzo Molare area yield $\mathrm{Alm}_{0.62} \operatorname{Prp}_{0.06} \mathrm{Grs}_{0.23} \mathrm{Sps}_{0.09}$ for the core and $\mathrm{Alm}_{0.68} \operatorname{Prp}_{0.12} \mathrm{Grs}_{0.20} \mathrm{Sps}_{0.00}$ for the rim. The An-content of plagioclase ranges between 0.16 and 0.30 . The more calcareous chemistry of the Valaisan Bündnerschiefer does not allow for the growth of these new minerals; the assemblage biotite - plagioclase - zoisite/clinozoisite - titanite - phengite - quartz - calcite/dolomite \pm chlorite still persists in this metamorphic zone.

\subsection{Correlations between the structural and metamorphic evolution}

The early HP/LT event was associated with the formation of quartz-calcite veins containing pseudomorphs after $\mathrm{Fe}-\mathrm{Mg}$ carpholite indicating blueschist facies conditions. We infer that these veins formed during D1 since they were folded by isoclinal F2 folds (Figs. 5b, c \& d). These isoclinal folds are associated with a D2 penetrative axial planar foliation that formed under greenschist-facies conditions. From this we deduce that greenschist-facies conditions were already established during D2.

Porphyroblasts related to Barrow-type thermal overprint, such as chloritoid, zoisite/clinozoisite, titanite, plagioclase, biotite, garnet, kyanite, staurolite and amphibole, all clearly overgrow the S2/S3 composite main foliation and have no shape preferred orientation (Figs. 8a \& b). Big flakes of biotite typically grow across the S2/S3 main foliation ("Quer-Biotit"). This implies a temporal hiatus between syn-D1 HP/LT metamorphism and post-D2/D3 Barrow-type overprint. Moreover, the random orientation of porphyroblasts related to Barrow-type thermal overprint, as well as the conservation of an unfolded internal S2/S3 compositional foliation in the cores of garnets (Fig. 8b), both indicate that at least the initial stages of the Barrovian overprint occurred under static conditions in most parts of the working area. The famous syn-D4 snowball garnets (Chadwick 1968; Fox 1975; Robyr et al. 2007) represent an exception and are restricted to a specific level of the Stgir Series.

In most places the Barrovian mineral assemblages have been overprinted by D4 crenulation deformation; needles and prisms of chloritoid, zoisite/clinozoisite and kyanite are kinked, bent or broken (Figs. 8c \& d). Most garnet porphyroblasts show some rotation of the internal S2/S3 foliation towards the rims (Fig. 8b), indicating that the last stages of the garnet growth occurred during D4. However the D2/D3 composite foliation is strongly crenulated in the rock-matrix outside of the garnet, indicating that most of the D4 crenulation post-dates the growth of garnet. 

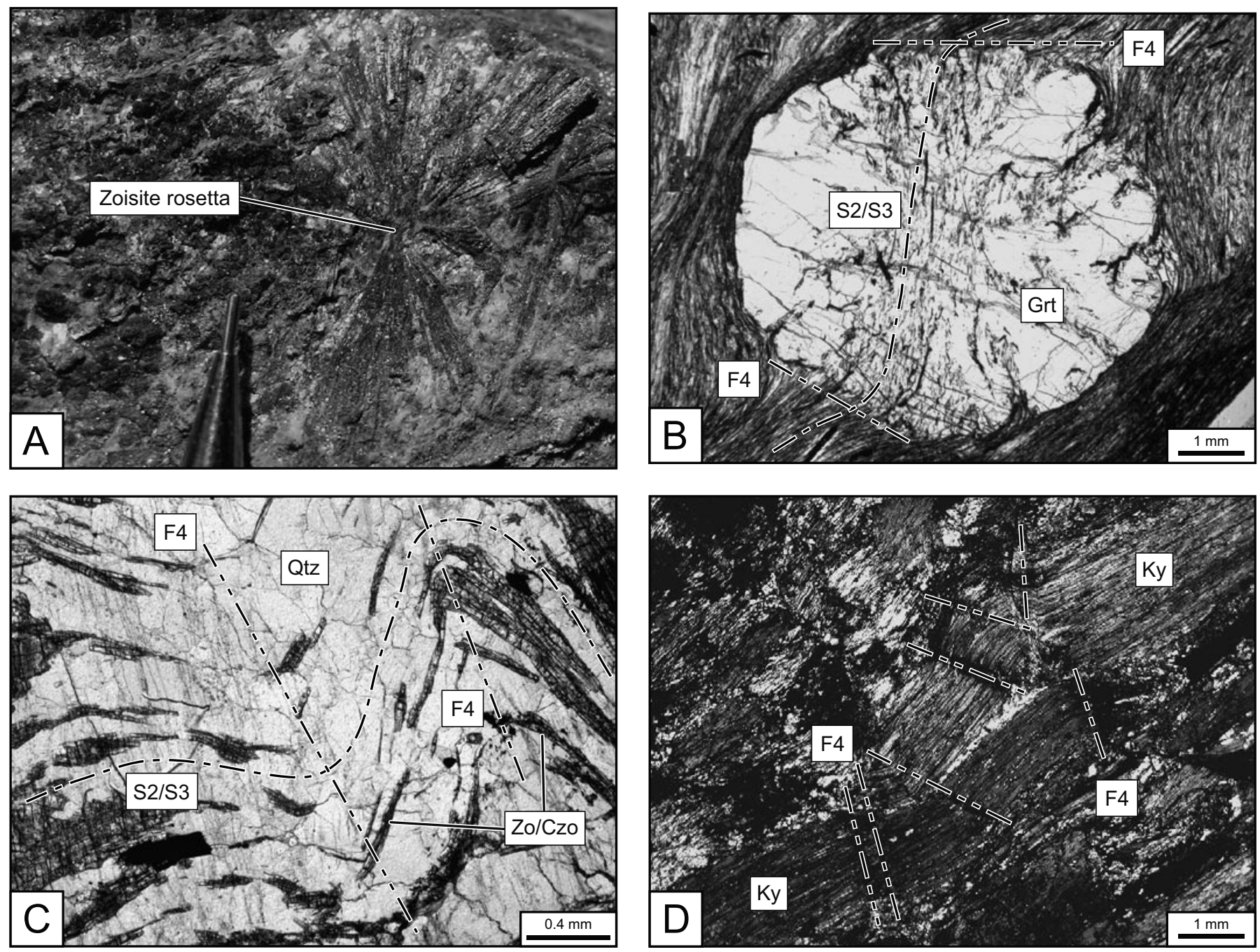

Fig. 8. Photographs showing microstructural relationships between porphyroblasts related to Barrowian overprint and deformation phases. (A) Rosetta of zoisite growing over the S2/S3 composite main foliation (Val Luzzone, 716'469/158'124,1450 m). (B) Straight internal S2/S3 composite foliation inside a garnet porphyroblast (Grt), slightly curving at the rim; deflection of the S2/S3 foliation around the garnet and its relative rotation are the effects of subsequent D4 deformation (Val Luzzone, 715'029/156'841, $1190 \mathrm{~m}$ ). (C) Zoisite/clinozoisite needles (Zo/Czo) oriented parallel to the S2/S3 composite main foliation are broken and bent by D4 deformation (Val Luzzone, 716'093/157'771,1390 m). (D) Needles of kyanite (Ky) kinked by D4 folds (S of Pizzo Molare, 709'541/149'308, 2310 m).

In summary (see Figs. 9 \& 10), the Barrovian-type thermal overprint definitely post-dates D3 and started during a period without any significant deformation. The HP/LT event, however, was syn-D1 and terminated before D2. This implies that greenschist facies conditions were already established during decompression from the HP/LT stage and before the Barrowtype heating event.

\subsection{Relations between HP/LT and MP/MT metamorphism: Significance of a metamorphic field gradient}

Pressure-dominated metamorphic event

Peak-pressure and -temperature conditions can be estimated from the composition of coexisting phengite, Fe-Mg carpholite, and chloritoid according to Bousquet et al. (2002). P-T calculations were carried out with the GEO-CALC software (Brown et al. 1988), by using the updated JAN92.RGB thermodynamic database (Berman 1988), Mg-carpholite data from Vidal et al. (1992), Mg-chloritoid data of B. Patrick (listed in Vidal \& Theye 1996), and alumino-celadonite data from Massonne (1995). The mineral activities used are listed in Bousquet et al. (2002). In the working area, the measured mineral compositions of Fe-Mg carpholite, phengite, and chloritoid are similar to those described by Goffé \& Oberhänsli (1992), Oberhänsli et al. (1995) and Bousquet et al. (2002). The pressure conditions for carpholite-bearing rocks are defined by the location of the equilibrium (Fig. 11):

2 phengite + chlorite +5 Quartz $+2 \mathrm{H}_{2} \mathrm{O}=3$ carpholite +2 phengite $(\mathrm{R} 1)$

S140 M. Wiederkehr et al. 
while the stability field of Fe-Mg carpholite towards higher temperature is limited by the equilibrium:

carpholite $=$ chloritoid + quartz $+2 \mathrm{H}_{2} \mathrm{O}(\mathrm{R} 2)$

From the mineral chemistry of the observed mineral assemblage and the position of the above-described equilibria, peak metamorphic conditions of $1.2-1.4 \mathrm{GPa}$ and $350-400{ }^{\circ} \mathrm{C}$ are estimated for both Lower Penninic Bündnerschiefer and Sub-Penninic meta-sediments of the Peidener Schuppenzone
(Fig. 11), similar to the P-T conditions estimated in the Safiental further to the east (Bousquet et al. 2002).

Most of the meta-sediments show retrogressed greenschistfacies assemblages documented by the widespread mineral assemblage phengite - paragonite - chlorite - quartz - calcite/ dolomite. However, the preservation of Fe-Mg carpholite relics, as well as a retrograde path mainly characterised by the decay of $\mathrm{Fe}-\mathrm{Mg}$ carpholite to chlorite and phengite (following R1; Fig. 11) forming pseudomorphs after carpholite, implies a

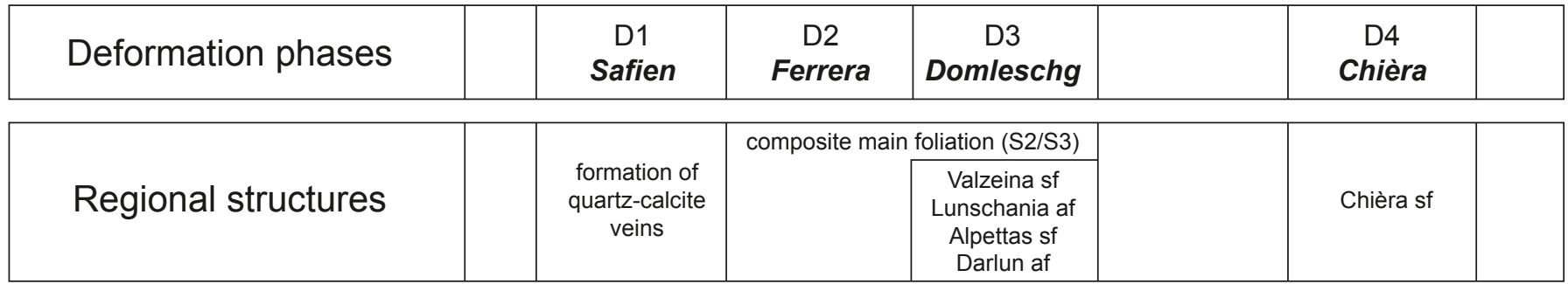

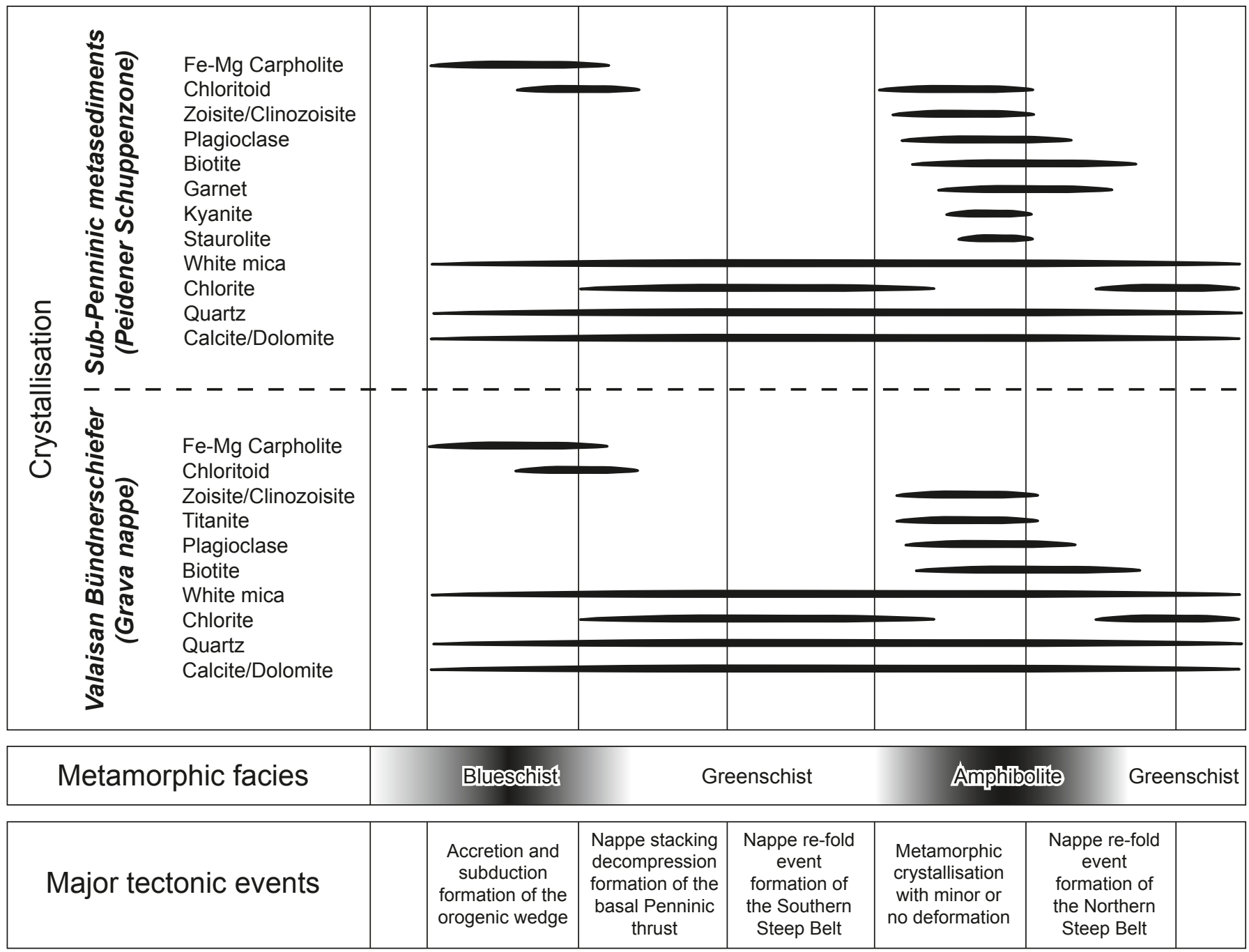

Fig. 9. Summary of relationships between crystallisation and deformation in the Lower Penninic and Sub-Penninic meta-sediments; sf: synform, af: antiform. 

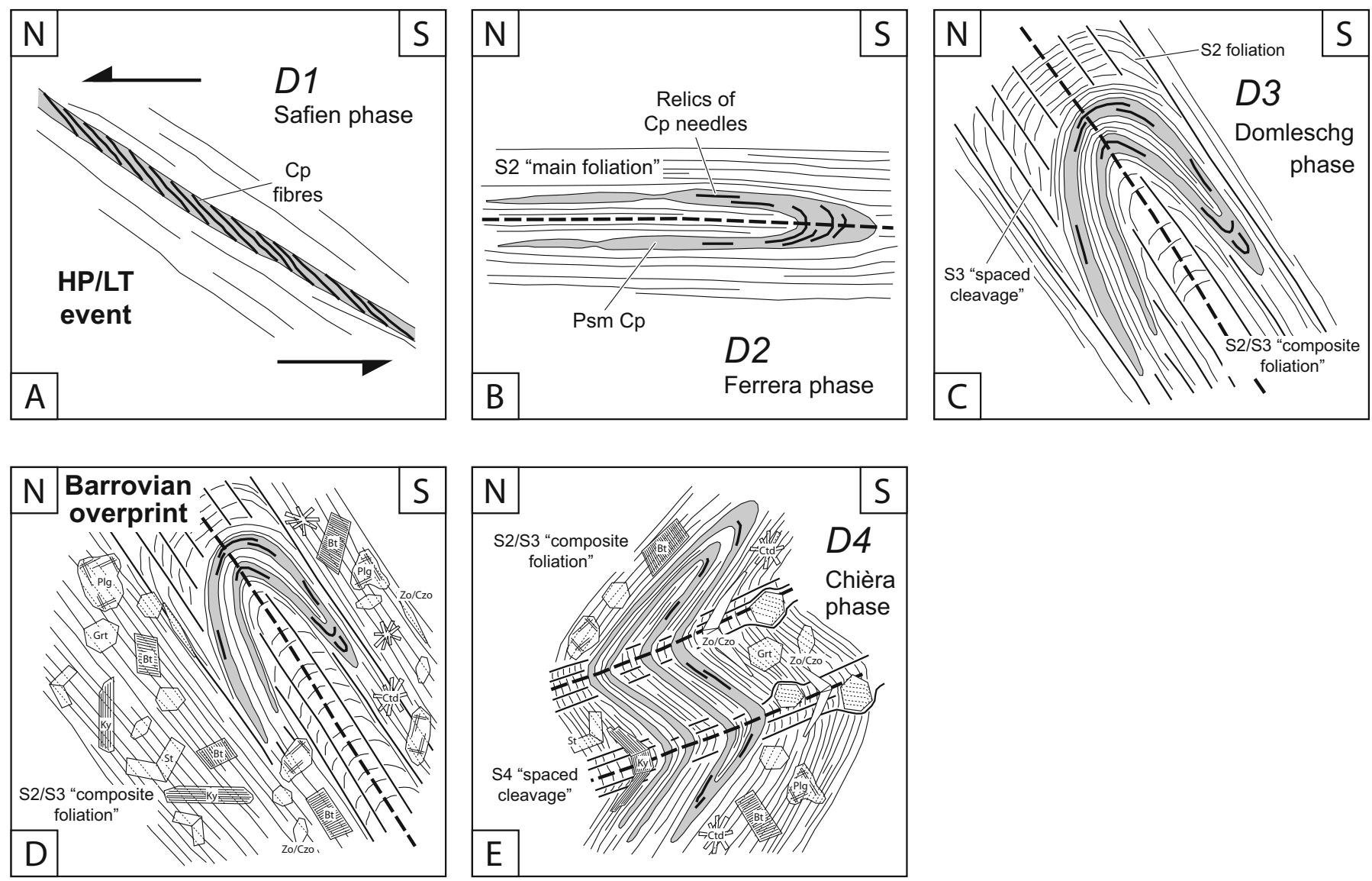

Fig. 10. Schematic sketches illustrating the tectono-metamorphic evolution in the study area. (A) Formation of fibrous quartz-calcite veins and Fe-Mg carpholite related to the HP/LT event, i.e. subduction (D1, Safien phase). (B) Pseudomorphs after carpholite, refolded by D2 (Ferrera phase), associated with the formation of the main penetrative foliation S2. (C) main foliation and earlier formed pseudomorphs after carpholite, refolded by D3 (Domleschg phase) and overprinted by a new spaced cleavage S3. (D) Amphibolite-facies Barrovian overprint leading to the growth of new porphyroblasts over the pre-existing S2/S3 composite foliation under static conditions. (E) D4 (Chièra phase), refolding the quartz-calcite veins a third time and deforming the amphibolite-facies mineral assemblages.

cold (or fast) decompression path after the HP/LT metamorphic stage (Gillet \& Goffé 1988). In the Engadine window and in Safiental, no re-heating during this decompression can be evidenced from the observed mineral assemblages (Bousquet et al. 1998).

Temperature-dominated, Barrow-type overprint: Results based on graphite-thermometry

The P-T conditions are only well constrained for the pelitic rocks of the Sub-Penninic sediments in the south-western part of the working area, around Pizzo Molare and the area between Olivone and southern Lukmanier. There, earlier investigations yielded $500-550{ }^{\circ} \mathrm{C}$ and $0.5-0.8 \mathrm{GPa}$ (Frey 1969; Fox 1975; Engi et al. 1995; Todd \& Engi 1997; Frey \& Ferreiro Mählmann 1999). In order to provide more information on the temperature gradient from NE to SW associated with the Barrow-type amphibolite facies overprint, we performed graphite-thermometry following the procedure proposed by Beyssac et al. (2002). The method is based on the degree of crystallisation of organic material, which is mainly temperature dependent (Buseck \& Bo-Jun 1985). Relationships between grade of crystallisation and metamorphic conditions are empirically calibrated (Beyssac et al. 2002). Since graphitisation of organic matter is strictly irreversible (Pesquera \& Velasco 1988) this geothermometer always records the peak temperature reached by a rock specimen along its P-T loop, with a relative accuracy in the order of $10-15{ }^{\circ} \mathrm{C}$ (Beyssac et al. 2004). Here we only present the main results of this analysis of the "field thermal gradient" (Bollinger et al. 2004); details on method and results will be published elsewhere.

The peak temperatures derived from the Raman spectra obtained from over 140 samples collected between the Lucomagno/Pizzo Molare area in the west and Safiental in the east continuously increase from $350{ }^{\circ} \mathrm{C}$ in Safiental to $570{ }^{\circ} \mathrm{C}$ at the Pizzo Molare over an amazingly short distance along strike (Fig. 12). Most of this increase in temperature occurs in the Val Luzzone, i.e. between Piz Terri and Olivone. Further east a fairly homogeneous temperature between 350 and $400{ }^{\circ} \mathrm{C}$, with only a moderate gradient, has been deduced. 


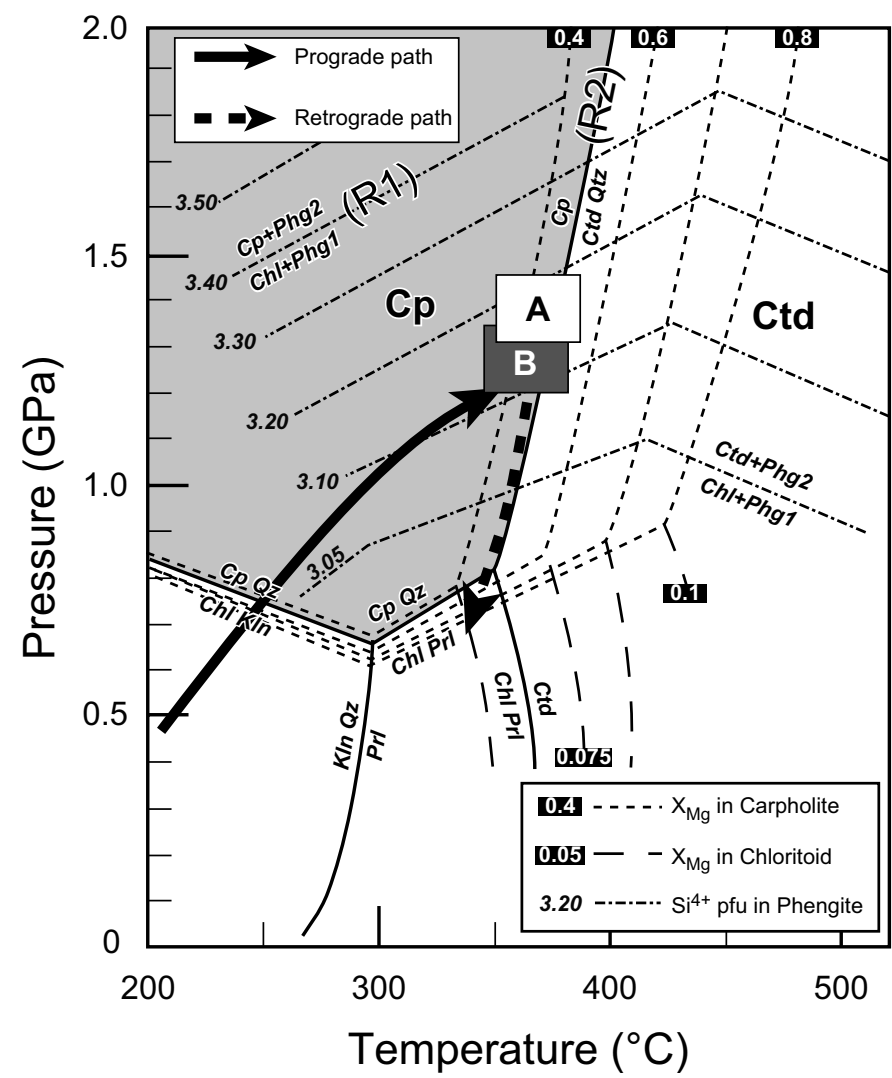

Fig. 11. Estimated P-T conditions for the North Penninic Bündnerschiefer (A) and the Sub-Penninic (European) meta-sediments (Peidener Schuppenzone, B). P-T conditions have been estimated for Fe-Mg carpholite-phengite-chlorite-quartz \pm chloritoid assemblages (only preserved in quartz-calcite veins) using the chemistry of the different minerals (Table 1) according to reactions R1 \& R2 (see explanations in the text). Peak-pressure conditions were established very close to the position of the reaction R2, as is documented by the scarce occurrences of chloritoid that formed by the breakdown of Fe-Mg carpholite along the prograde path, i.e. during the HP/LT stage. The preservation of both $\mathrm{Fe}-\mathrm{Mg}$ carpholite and associated rare occurrences of HP/LT chloritoid imply near-isothermal decompression from the HP/LT stage (Bousquet et al. 1998). Petrogenetic grid for HP/LT metapelites after Bousquet et al. $(2002,2008)$.

Comparison of the resulting temperature distribution pattern with the geological structures yields the following observation: In the south-west, the "isotherms" clearly cut all D2 nappe contacts and D3 post-nappe mega-folds, while in the north-east the " $425^{\circ} \mathrm{C}$ isotherm" is folded around the large scale D3 Lunschania antiform (Fig. 12). This shows that the peak temperatures were reached at different times and under different metamorphic conditions in the east and west. The post-D3 temperature increase in the SW is related to the later Barrow-type overprint. The folded isotherms in the NE, however, indicate that the temperatures derived for this area are "older", i.e. they pre-date the onset of the Barrovian overprint and are hence related to the high-pressure event and/or greenschist facies overprint that followed isothermal decompression. This in turn implies that a Barrow-type overprint possibly did not exist at all in the north-east, or was only associated with temperatures lower than $425^{\circ} \mathrm{C}$, i.e. temperature ranges previously reached during the blueschist and/or greenschist facies event.

The temperatures determined by Raman microscopy of carbonaceous rocks are in excellent agreement with previously published temperature estimates based on traditional methods in the SW part of the working area $\left(500-550{ }^{\circ} \mathrm{C}\right.$; e.g. Frey \& Ferreiro Mählmann 1999). They also indicate temperatures of $500-550{ }^{\circ} \mathrm{C}$, reaching $570{ }^{\circ} \mathrm{C}$ in the Pizzo Molare area. In the north-east the inferred temperatures $\left(<425-375^{\circ} \mathrm{C}\right)$ are near those inferred for the blueschist facies peak-pressure with traditional methods, ranging between $350-400{ }^{\circ} \mathrm{C}$ according to our study and that of Bousquet et al. (2002), as well as near those obtained for the greenschist facies overprint in the Grisons area $\left(400{ }^{\circ} \mathrm{C}\right.$; Rahn et al. 2002).

The superposition of a Barrow-type over an earlier HP/ LT evolution clearly indicates that the notion of a metamorphic field gradient can lead to misinterpretations. Strictly, a metamorphic field gradient primarily reflects the presentday distribution of pressure and/or temperature and cannot a priori be interpreted in terms of a particular geodynamic evolution.

\section{Discussion and interpretation of the results}

In the following we discuss the results obtained within the working area in a regional context and address the timing of the geodynamical evolution of the Alps. Then, in a qualitative way, we discuss possible heat sources that could be held responsible for Barrovian metamorphism in the north-eastern part of Lepontine thermal dome.

\subsection{Regional correlations of the tectono-metamorphic evolution established in the working area and timing constraints}

The D3 and D4 deformation phases led to the major features that are visible in map (Figs. $1 \& 2$ ) and cross-section (Fig. 3) view. D4 deformation resulted in the cascade-like geometry formed by a set of parasitic syn- and antiforms in the western part of the working area (Fig. 3), related to the formation of the Chièra synform which is well-developed only west of the working area (Milnes 1976; Etter 1987). There, the composite D2/D3 main foliation generally steeply dips northward and represents the overturned nappe-stack characterising the Northern Steep Belt. In our study area (Val Luzzone, Piz Terri, Val Lumnezia) the Chièra synform is only weakly developed, and instead, a series of cascade-like D4 syn- and antiforms overprint the D3 Lunschania antiform; these gradually fade out further to the east. The overall geometry of the cross section in Figure 3 is characterised by progressive steepening of the main foliation from a sub-horizontal orientation in the south to a generally moderate southward dip in the north that is produced by this D4 folding; subvertical and overturned composite D2/D3 foliations and nappe contacts are restricted to the structurally lowest levels. 


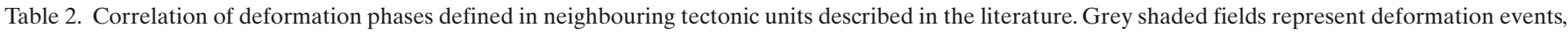

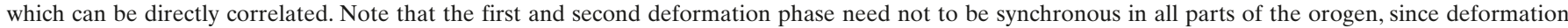
phases related to the accretionary stage migrated from internal to external. See text for further discussion of the timing constraints.

\begin{tabular}{|c|c|c|c|c|c|c|c|c|c|c|}
\hline \multirow{7}{*}{ 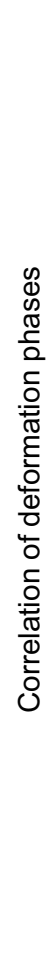 } & $\begin{array}{l}\text { This study } \\
--------- \\
\text { Major tectonic events }\end{array}$ & ----- & $\begin{array}{c}\text { D1 } \\
\text { Safien } \\
---- \\
\text { Accretion and } \\
\text { subduction } \\
\text { formation of the } \\
\text { orogenic wedge }\end{array}$ & - & $\begin{array}{c}\text { D2 } \\
\text { Ferrera } \\
----- \\
\text { Nappe stacking } \\
\text { decompression } \\
\text { formation of the } \\
\text { basal Penninic } \\
\text { thrust }\end{array}$ & ------ & -----1 & \begin{tabular}{l} 
D3 \\
Domleschg \\
\hdashline---- \\
Nappe re-fold \\
event \\
formation of \\
the Southern \\
Steep Belt
\end{tabular} & $\begin{array}{l}----- \\
\text { Metamorphic } \\
\text { crystallisation } \\
\text { with minor or } \\
\text { no deformation }\end{array}$ & \begin{tabular}{|} 
D4 \\
Chièra \\
------ \\
Nappe re-fold \\
event \\
formation of \\
the Northern \\
Steep Belt
\end{tabular} \\
\hline & Timing constraints & & & & & & $\begin{array}{l}\text { Bergell intrusion } \\
(32-30 \mathrm{Ma})\end{array}$ & & $\begin{array}{l}\text { Metamorphic } \\
\text { crystallisation } \\
(20-18 \mathrm{Ma}) \\
\text { by mica (Ar-Ar), } \\
\text { monazite (U-Pb) }\end{array}$ & \\
\hline & $\begin{array}{l}\text { Northern Steep Belt } \\
\text { Chadwick }(1968)-1- \\
\text { Thakur }(1971)-1-- \\
\text { Etter }(1987)-1- \\
\text { Probst }(1980)\end{array}$ & & $\begin{array}{l}---- \\
---- \\
----\end{array}$ & $\begin{array}{l}-- \\
-- \\
--\end{array}$ & $\begin{array}{l}--\overline{\mathrm{F} 1}-\cdot \\
--\frac{\mathrm{D} 1}{\mathrm{~B} 1, \overline{\mathrm{B}} 2}\end{array}$ & $\begin{array}{l}------ \\
------\cdot \\
------\end{array}$ & $\begin{array}{l}----- \\
----- \\
-----\end{array}$ & $\begin{array}{l}-\frac{\text { Phase B }}{\bar{F} 2}- \\
--\frac{\overline{\mathrm{F}}}{\mathrm{D} 2}-- \\
-\overline{\mathrm{B} 3, \mathrm{~B} 4}-\end{array}$ & $\begin{array}{l}----- \\
----- \\
-----\end{array}$ & $\begin{array}{l}-\frac{\text { Phase V }}{-}-\frac{\mathrm{F}}{3}-- \\
-\frac{\mathrm{D} 3}{\mathrm{~B} 5}--\end{array}$ \\
\hline & $\begin{array}{l}\text { Pennine } \\
\text { Schmid et al. (1996) }\end{array}$ & Avers & & & Ferrera & $\begin{array}{l}\text { Niemet- } \\
\text { Beverin }\end{array}$ & & Domleschg & & Chièra \\
\hline & 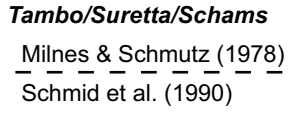 & - Avers & & & $-\frac{\text { Ferrera }}{-\frac{\mathrm{D} 1}{-}}$ & $---\frac{\text { Niemet }}{\mathrm{D} 2}-$ & ----- & $--\frac{-}{\mathrm{D} 3}--$ & ---- & --- \\
\hline & $\begin{array}{l}\text { Prättigau Half-Window } \\
\text { Weh \& Froitzheim (2001) }\end{array}$ & & D1a & & D1b & D2 & & D3 & & \\
\hline & $\begin{array}{l}\text { Northern Adula } \\
\text { Löw (1987) }\end{array}$ & & Sorreda & Zapport & Leis & & & $\begin{array}{c}\text { Carassino } \\
?\end{array}$ & & \\
\hline
\end{tabular}

Our D4-event corresponds to the deformation event which is responsible for the so-called Chièra synform (Milnes 1976, Etter 1987) and will be referred to as Chièra phase. This phase can be parallelised with phase V of Chadwick (1968), D3 of Etter (1987) and Thakur (1971) and $B_{5}$ of Probst (1980), as is summarised in Table 2. Schmid et al. (1997a) estimated the Chièra phase to have been active during the 25-20 Ma age interval. However, new ages in the $20-18$ Ma range, obtained on micas and monazite related to the Barrow-type overprint near our working area (Pizzo Molare and Val Piora area; Allaz et al. 2007; Janots et al. 2007), suggest a substantially younger, i.e. post-18 Ma age for this deformation event.

In Val Luzzone a set of D3 mega-folds was mapped.They are, from north to south: Valzeina synform, Lunschania antiform, Alpettas synform and Darlun antiform (Fig. 3). The profile construction of Fig. 3 shows that we favour a correlation of the D3 Valzeina synform with the D3 Molare synform. The Lunschania antiform is cored by the basement of the Soja nappe, which can be traced southwards into the nappe boundary between the Simano nappe and Adula nappe complex. Alpettas synform and Darlun antiform were overprinted, deformed and cut out by late-stage faulting at the front of the Adula nappe complex.

Our D3 phase corresponds to the Domleschg phase of Pfiffner (1977), who defined this phase east of the study area. We emphasise, however, that D3 deformation in the working area is by far more pervasive in comparison to areas further east, i.e. at higher structural levels. An age of D3 between 30 and $25 \mathrm{Ma}$ ago was inferred by Froitzheim et al. (1994) and Schmid et al. (1996), mainly based on the fact that this phase post-dates the Bergell intrusion. Its effects are widespread in the Lower and Middle Pennine nappes (Schmid et al. 1990; Baudin et al. 1993; Mayerat Demarne 1994; Marquer et al.1996; Weh \& Froitzheim 2001). To the west the D3 large-scale folds can easily be correlated (Table 2) with phase B of Chadwick (1968), D2 of Thakur (1971), $B_{3}-B_{4}$ of Probst (1980). Possibly, the Carassino phase of Löw (1987) represents a late stage of D3 deformation, as proposed by Etter (1987). This interpretation is mainly based on the fact that the axial planes of both Domleschg and Carassino phase steeply dip to the SSE. Parallelisation of the Carassino phase with the Domleschg phase implies that the Leis phase, only affecting the Adula nappe complex, has to be older than the Domleschg phase, as is documented by clear overprinting criteria between Leis and Carassino structures (Löw 1987). This rules out the correlation between Domleschg and Leis phase proposed by Schmid et al. (1996) and favours a relatively older age for the Leis phase, as was already proposed by Pleuger et al. $(2003,2008)$.

The older deformation phases are more difficult to correlate at a regional scale. D2 can best be correlated with the Ferrera phase, defined in the Schams, Tambo and Suretta nappes 


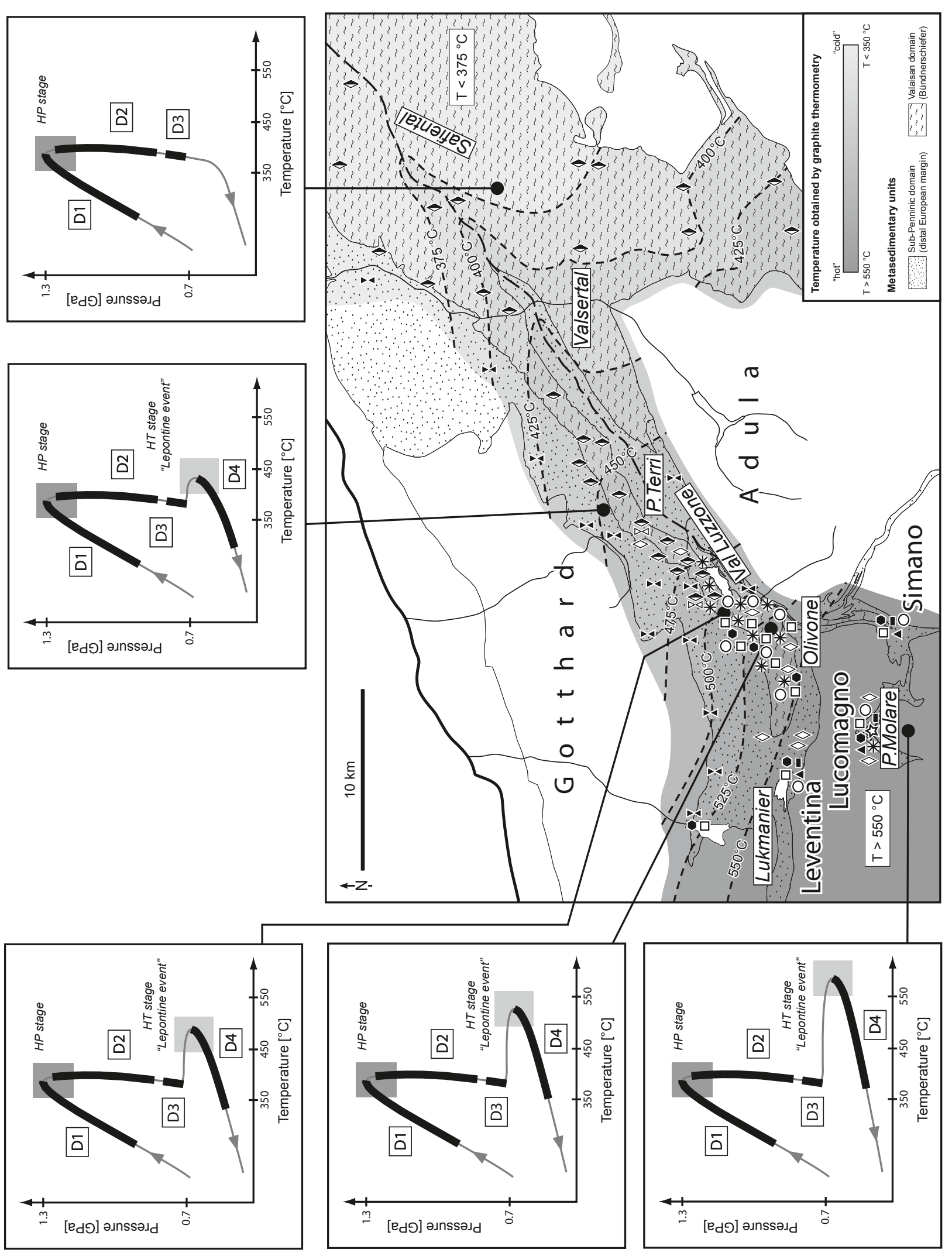

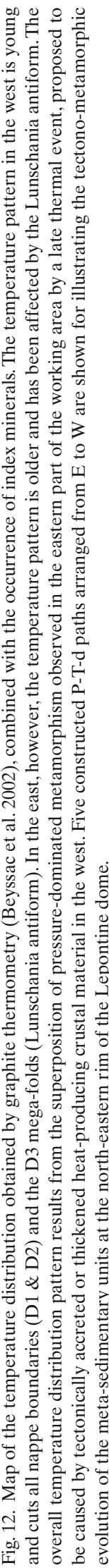


(Milnes \& Schmutz 1978; Schmid et al. 1990, 1996; Schreurs 1993), based on the fact that both these events are related to nappe stacking and that both are responsible for the formation of the first penetrative foliation. Weh and Froitzheim (2001) traced the Ferrera phase into the area of the Lower Penninic Bündnerschiefer (their D1a, b phase). It has to be emphasised, however, that the Ferrera phase was defined in a structurally higher level, i.e. the Middle Penninic Suretta nappe (Milnes \& Schmutz 1978). Hence, the correlation with our D2 in a geometrical and kinematic sense does not imply that deformation in this structurally lower level was contemporaneous with the Ferrera phase, active during the 56-35 Ma age interval in the area of the Middle Penninic nappes (Schmid et al. 1996) as also documented by radiometric dating in the Suretta nappe (46 $\pm 5 \mathrm{Ma}$; Challandes et al. 2003). We emphasise that not all structural correlations presented in Table 2 imply that deformation producing these structures was contemporaneous at the scale of the Alps.

In the Lower and Middle Penninic units east of our area of investigation, the Ferrera phase has been severely overprinted by the Niemet-Beverin phase, which represents a first nappe refolding stage, resulting in large scale back-folding and inverting the nappe pile in the upper limb of the recumbent Niemet-Beverin mega-fold (Milnes \& Schmutz 1978; Schmid et al. 1990; Schreurs 1993; Mayerat Demarne 1994; Weh \& Froitzheim 2001; Pleuger et al. 2003). Interestingly, no effects of this Niemet-Beverin phase (35-30 Ma; Schmid et al. 1996) were found in our area of investigation. Therefore, it is theoretically possible that the D2-event (Ferrera phase) could have lasted until some $30 \mathrm{Ma}$ ago in our study area, i.e. at a much deeper structural level and in units occupying a more external paleogeographical position.

D1-deformation related to formation of quartz-calcite segregations, pre-dating $\mathrm{D} 2$ of the working area, corresponds to the sub-stage D1a of Weh and Froitzheim (2001; Table 2). These authors proposed that the formation of tight to isoclinal folds (their D1b; our D2) post-dates the formation of Fe-Mg carpholite-bearing veins associated with the formation of a penetrative foliation during their D1a (our D1). An estimate on the age of D1 in the working area may be obtained by considering the fact that D1 is linked with thrusting along the Penninic Basal Thrust, whose age is constrained by the age of the youngest sediments involved. Sedimentation in the Lower Penninic Bündnerschiefer realm lasted until Lowest Eocene times (i.e. some $50 \mathrm{Ma}$ ago) according to Weh \& Froitzheim (2001), but until Bartonian times (i.e. some $40 \mathrm{Ma}$ ) in the Sardona Unit (Lihou \& Allen 1996). The paleogeographical position of the Sardona Unit is considered Ultra-Helvetic by some authors (e.g. Lihou \& Allen 1996) but Penninic by others (mainly based on sedimentological and age criteria; e.g. Trümpy 1980; Hsü \& Briegel 1991). Regardless of its precise paleogeographical position, it is extremely unlikely that the Sardona Flysch is of more external origin in respect to the Ultrahelvetic sediments of the Peidener Schuppenzone, given its high content of siliciclastic detritus partly shed from the "North Prättigau High" (Lihou \&
Allen 1996). Hence, D1-deformation, sediment-accretion and blueschist facies overprint are unlikely to have started before the Bartonian, i.e. before some $40 \mathrm{Ma}$ ago.

Interestingly, the main nappe stacking Ferrera phase also post-dates an early thrusting event formed under HP/LT conditions, known as the Avers phase (Milnes \& Schmutz 1978; Schmid et al. 1997b; Wiederkehr 2004) in the BriançonnaisPiemont-Liguria Ocean contact area in the Avers. However, since the Avers phase is related to the closure of the PiemontLiguria Ocean during the Late Paleocene (Schmid et al. 1996), it must substantially pre-date the D1 event in our working area, which is related to the closure of the more northerly Valais Ocean.

In summary, this study could, for the first time in the investigated area, decipher the existence of an early blueschistfacies tectono-metamorphic event related to subduction and sediment-accretion. We refer to this event as the Safien phase (Table 2, Figs. 9 \& 10). In contrast to Weh \& Froitzheim (2001; their D1a and D1b), we emphasise a clear separation between the D1 and D2 events. This separation is supported by the fact that D2 formed under greenschist facies conditions. The age of the HP/LT Safien phase is constrained to post-date Bartonian times, i.e. $40 \mathrm{Ma}$. D2 deformation in our area is probably younger than the Ferrera phase in the Schams area; it probably lasted until the onset of D3-deformation, i.e. some $30 \mathrm{Ma}$ ago. The onset of Barrow-type overprint, which post-dates D3 (i.e. $25 \mathrm{Ma}$ according to the correlation of D3 with the age of the Domleschg phase; Schmid et al. 1996) is likely to be very much younger in respect of the high-pressure event. Given an almost static interval of mineral growth and the new radiometric dating of Barrow-type metamorphism in the area (Allaz et al.2007; Janots et al.2007), this heating pulse post-dates $20 \mathrm{Ma}$.

\subsection{P-T-d-t path and reconstruction of the regional tectono-metamorphic evolution}

The complex metamorphic evolution characterised by an early HP/LT stage $\left(350-400{ }^{\circ} \mathrm{C}, 1.2-1.4 \mathrm{GPa}\right)$, later overprinted by a Barrow-type amphibolite facies event $\left(500-570{ }^{\circ} \mathrm{C}, 0.5-0.8\right.$ $\mathrm{GPa}$ ) can be reconciled with either of two different P-T path trends: (1) A single P-T loop whereby the amphibolite facies overprint results from heating during decompression after $\mathrm{HP} /$ LT metamorphism, or alternatively, (2) a two-stage P-T evolution, whereby the amphibolite facies Barrovian overprint represents a separate heating pulse that follows earlier isothermal or cooling decompression from HP/LT conditions (Fig. 13). For the reconstruction of the regional tectono-metamorphic evolution and the interpretation of the geodynamic scenario, it is crucial to obtain constraints on the shape of the P-T path and its timing.

The following facts argue for isothermal or slightly cooling decompression of the Lower Penninic Valaisan Bündnerschiefer and the Sub-Penninic Peidener Schuppenzone after the HP stage: (1) very good preservation of $\mathrm{Fe}-\mathrm{Mg}$ carpholite east of the study area (Engadine window), (2) its replacement

S146 M. Wiederkehr et al. 
exclusively by a lower pressure mineral assemblage (phengite-chlorite-quartz) within the studied area, and (3) the preservation of both pseudomorphs and relics of Fe-Mg carpholite within the north-eastern Lepontine dome. Hence, the breakdown of carpholite in the Valaisan of the study area is entirely pressure-controlled and not associated with a temperature increase.

The analysis of the relationships between deformation and metamorphism and the timing constraints provide additional arguments in favour of a two-stage P-T-evolution characterised by a separate heating pulse that followed isothermal or cooling decompression from earlier HP/LT metamorphic conditions:

1) Both metamorphic events are separated from each other by two deformation phases implying a considerable time gap between them. The HP/LT event predates D2 and was estimated to have started ca. $40 \mathrm{Ma}$ ago, certainly before $30 \mathrm{Ma}$ (onset of D3-deformation). Barrow-type amphibolite facies overprint post-dates D2 nappe stacking and a first nappe re-folding event D3 (30-25 Ma), and hence, was younger than 20 Ma (Figs. 9 \& 10).

2) Substantial decompression was associated with D2 nappe stacking and therefore predates the heating pulse that took place after D3.

3) The increase in temperature took place under more or less static conditions between D3 and D4.

4) Graphite thermometry documents a two-stage temperature distribution pattern. The D3 Lunschania antiform folded an older HP/LT-related pattern and a younger, onion-shaped pattern cutting the D3 Lunschania antiform was associated with Barrovian amphibolite facies overprint (Fig. 12).

We propose the following 5-stage scenario regarding the tectono-metamorphic evolution in the area (Fig. 14):

(1) Subduction and sediment-accretion stage (Safien phase): The Lower Penninic Bündnerschiefer of the Grisons area (mainly Grava and Tomül nappes) that today build up a $20 \mathrm{~km}$ thick accretionary wedge of meta-sediments (Hitz \& Pfiffner 1997) formed during Cenozoic subduction of the Valais Ocean and the distal European margin beneath the Briançonnais micro-continent. Deeper parts of this sedimentary accretionary wedge experienced pressure-dominated metamorphism under blueschist facies conditions $\left(350-400{ }^{\circ} \mathrm{C}, 1.2-1.4 \mathrm{GPa}\right)$, including parts of the sedimentary cover in Ultrahelvetic facies (Peidener Schuppenzone), which were detached from their crystalline basement and incorporated into the HP/LT part of the accretionary wedge. The associated deformation (D1 Safien phase) was semi-ductile and led to the formation of shear fibre veins consisting of quartz, calcite and $\mathrm{Fe}-\mathrm{Mg}$ carpholite. Exact timing of this HP/LT subduction and sediment-accretion stage is not yet possible. It is, however, constrained to have occurred during the Late Eocene (after 40 but before $30 \mathrm{Ma}$ ago; see Berger \& Bousquet 2008), hence substantially after similar but Late Paleocene to Middle Eocene high-pressure stages pro-

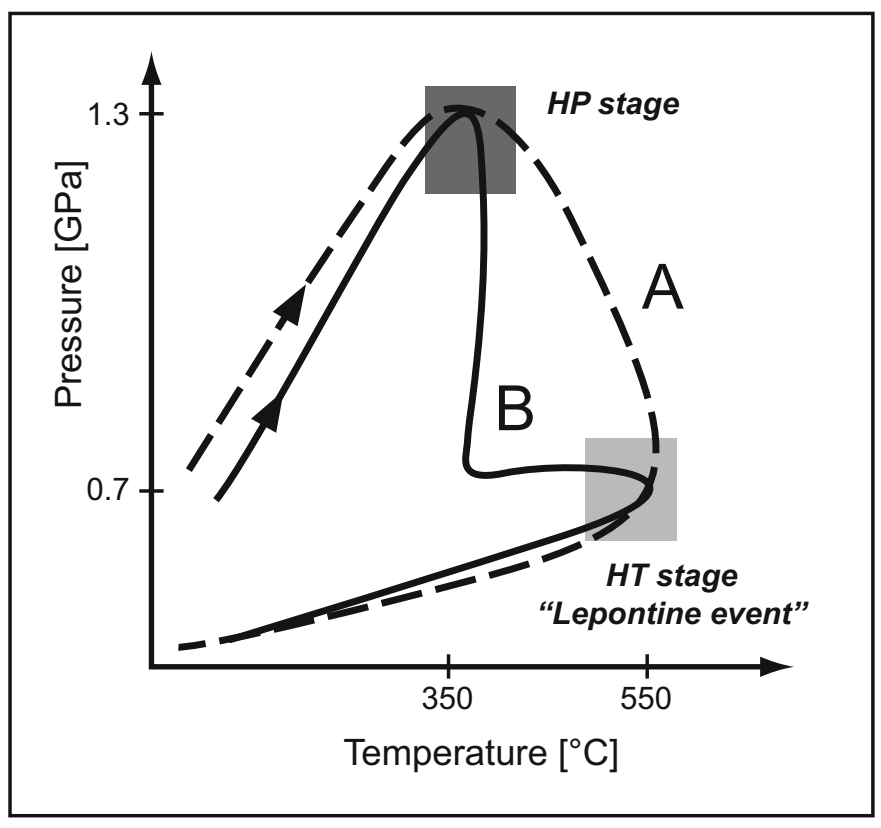

Fig. 13. Alternative P-T paths connecting the HP/LT event and the amphibolite-facies Barrovian overprint. Path A is a single P-T path, decompressional heating of the HP/LT stage leading to Barrovian overprint. Path B is characterised by a two-stage P-T path, Barrovian overprint represented by a separate heating pulse that follows isothermal or cooling decompression.

posed for the Middle and Upper Penninic units (see overviews given by Froitzheim et al. 1996; Schmid et al. 2004; Berger \& Bousquet 2008; Bousquet et al. 2008).

(2) Nappe stacking and decompression stage (Ferrera phase): Nappe stacking was associated with substantial decompression of the blueschist-facies rocks. The presence of relics of Fe-Mg carpholite indicates decompression under isothermal or cooling conditions. This thermal regime, as well as ongoing accretion of the rest of the Sub-Penninic sediments (Scopi Unit, Fig. 3), suggests that also European continental basement rocks, such as preserved in the Adula, Simano and Leventina-Lucomagno units, became involved in ongoing subduction and accretion during the Ferrera phase. We propose that the Ferrera phase in our working area may have outlasted earlier stages of the nappe-stacking Ferrera phase that affected the Middle Penninic units (e.g. Baudin et al. 1993), and probably was active until 30 Ma ago.

(3) Nappe re-folding (Domleschg phase): This D3 nappe folding event substantially modified the Penninic nappe stack in the working area. It post-dates an earlier nappe re-folding phase established only within structurally higher North and Middle Penninic nappes east of the working area (Niemet-Beverin phase; e.g. Schreurs 1993; Baudin et al. 1993; Marquer et al. 1996; Weh \& Froitzheim 2001). D3 deformation produced tight to isoclinal mega-folds with amplitudes up to some $10 \mathrm{~km}$ (Figs. 3 \& 14): the most prominent Lunschania antiform, but 
also the Valzeina and Alpettas synforms, as well as the Darlun antiform (Voll 1976; Kupferschmid 1977; Probst 1980; Steinmann 1994a, b; Weh \& Froitzheim 2001; Uhr unpubl.; Figs. 1, $2 \& 3)$. On the scale of the entire Alpine orogen the Domleschg phase, characterised by far less intense folding at higher structural levels, is interpreted as contemporaneous with back thrusting along the Insubric mylonite belt (Schmid et al. 1987), which occurred during the 30-25 Ma time interval (see discussion given in Schmid et al. 1997b). Note also that this phase is associated with ongoing accretion of continental basement (i.e. Lucomagno-Leventina nappe, Fig. 14). Regarding the eastern part of the investigated area, the tectono-metamorphic evolution essentially came to a halt after D3 deformation (Fig. 12). The following metamorphic and tectonic events only affected the western part of the working area.

(4) Barrow-type thermal overprint: This thermal pulse occurred during a tectonically quiescent phase within the working area (but not necessarily elsewhere, i.e. in the more external parts of the Alps), initiating shortly after some $20 \mathrm{Ma}$ ago. Increasing temperatures led to the formation of porphyroblasts related to classical Barrow-type amphibolite facies overprint. This thermal overprint was sustained until the beginning stages of the last tectonic (D4) event (Figs. 12 \& 14).

(5) Back-folding in the Northern Steep Belt (Chièra phase): This second nappe re-folding event leads to back-folding within the Gotthard "massif" and adjacent areas. It is associated with the formation of the Northern Steep Belt of the Penninic realm that is well developed only west of our area of investigation (Milnes 1974). D4 deformation is intense in the south-west but gradually becomes weaker towards the north-east and, finally, fades out somewhere east of the Piz Terri-Vrin area (Figs. 2 \& 3). A relatively tight synform, the Chièra synform (Milnes 1974; Milnes 1976; Etter 1987), brings the Lower Penninic and SubPenninic nappe stack into an overturned, steeply north dipping position (Northern Steep Belt) at the deepest structural levels. Within most of the working area, a set of parasitic syn- and antiforms develops, structurally located between the Chièra synform and the more northerly located corresponding Greina or Gotthard antiform (Thakur 1973) which brings the overturned nappe pile back into a normal position (Fig. 3). Hence, backfolding is much less pronounced in our working area compared to further west (Figs. $2 \& 3$ ). This folding outlasted Barrovian overprint (18-20 Ma; Allaz et al. 2007; Janots et al. 2007) and hence is very young (probably post-18 Ma) and contemporaneous with the $\mathrm{N}$-directed thrusting in the Aar massif in the more external parts of the Alps (Grindelwald phase; Burkhard 1988; Schmid et al. 1996; Pfiffner et al. 1997) and movements along the Simplon line associated with back folding west of the Lepontine dome (Steck 1984, 1990; Marquer \& Gapais 1985; Mancktelow 1992; Mancktelow \& Pavlis 1994; Steck \& Hunziker 1994; Keller et al. 2006).

We conclude that Barrovian overprint in the working area, representing a separate heating pulse (Fig. 14) is surprisingly young (18-20 Ma; Allaz et al. 2007; Janots et al. 2007) when compared to the timing of a similar separate heating pulse proposed for the Southern Steep Belt at around 30-27 Ma (Engi et al. 2001; Berger et al. 2005; Brouwer et al. 2005; Brouwer \& Engi 2005). Barrow-type overprint at the western edge of the Lepontine dome, which occurred along a single continuous P-T path, occurred before some $20 \mathrm{Ma}$ ago according to Keller et al. (2005).

Barrow-type metamorphism in the Lepontine area is often referred to as the Lepontine metamorphic event. The term "event" is totally misleading since Lepontine Barrow-type metamorphism, rather than representing one single event, is diachronous; thermal overprint becomes progressively younger towards the north (Köppel et al. 1981; Engi et al. 1995). Consequently, different relations between deformation and crystallisation are commonly observed (Berger et al. 2005). We emphasise that the separate heating pulse described in this study is characteristic for the north-eastern part of the Lepontine dome only and that no direct inferences in terms of timing, geodynamic setting or nature of the heat source should be drawn regarding the rest of the Lepontine area, particularly its southern part.

\subsection{Discussion of potential heat sources of Barrow-type overprint and thermal evolution}

We now discuss possible heat sources that could potentially be responsible for Barrovian metamorphism in the north-eastern part of the Lepontine thermal dome. We do this in a qualitative way, being aware of the complexities of the subject. We first briefly introduce the presently known potential heat sources and then qualitatively discuss which of these heat sources could best explain the observations.

The existence of a separate heating pulse raises the old and still widely debated question after the heat sources for Barrovian overprint in collisional orogens (e.g. Jamieson et al. 1998). The following potential heat sources have been proposed for Barrow-type thermal overprint: (1) Shear or viscous heating (Burg \& Gerya 2005). (2) Advective heat transfer by rising magma, i.e. plutons and dykes (Engi et al. 1995; Frey \& Ferreiro Mählmann 1999), possibly induced by up-welling of hot asthenosphere due to slab break-off (von Blanckenburg \& Davies 1995). (3) Advective heat transfer to the upper crust by exhumation of hot eclogitic slices within a subduction channel (Becker 1993; Engi et al. 2001), or alternatively, by extension-related exhumation of hot high-pressure rocks (Platt 1986; Ballèvre et al. 1990). (4) Accretion of continental crustal rocks characterised by high radioactive heat production (Chamberlain \& Sonder 1990; Bousquet et al. 1997; Huerta et al. 1998; Roselle et al. 2002; Goffé et al. 2003).

Discussions on shear heating need to (1) evaluate the expected spatial and temporal distribution of shearing-induced heat and (2) quantify the amount of heat produced, which depends on strain-rates and deformation mechanisms (e.g. Peacock 1996). In the case of the Alpine orogen such shear heating

S148 M. Wiederkehr et al. 


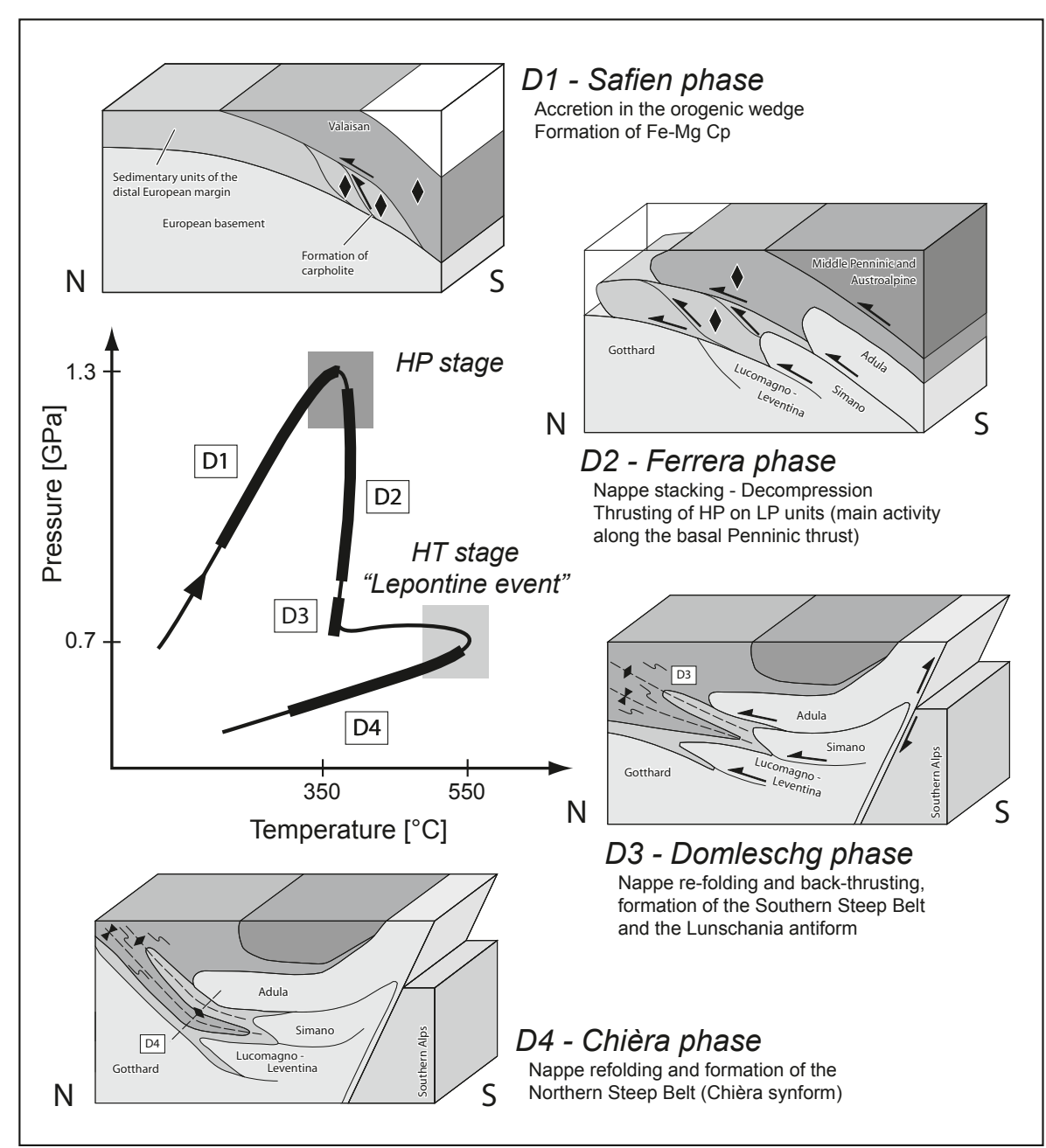

Fig. 14. P-T-d path for the Lower Penninic and Sub-Penninic (Peidener Schuppenzone) metasedimentary units and sketches of the geodynamic scenario during the various stages of the tectonometamorphic evolution. would be expected to lead to a thermal zonation, which parallels the strike of the orogen, i.e. parallel to the strike of the potential high-strain zones (in general nappe contacts and shear zones associated with the formation of the nappe-stack) that produce this heat. This, however, is not the case within the study area since isotherms are perpendicular to important structural elements, such as the Penninic Basal Thrust and other nappe contacts (Fig. 12). Moreover, plate convergence rates in the Alps are considered too low (in the order of $1 \mathrm{~cm}$ per year; Schmid et al. 1996) to produce enough heat at a nappe or orogen-wide scale, while this heat source may play a role in case of localised shear zones. Hence, only at high convergence rates can shear heating be an important heat source at a large scale. This, however, is not the case regarding the thermal overprint that occurred at a very late stage, i.e. when the Alpine edifice was essentially established. Moreover microstructural observations of porphyroblasts related to Barrovian metamorphism indicate that thermal overprint took place under more or less static conditions and was not at all associated with deformation. Based on field evidence we conclude that shear heating prob- ably had a rather limited influence on the thermal evolution in our working area.

The effect of advective heat transport by magma and/or local melt is also negligible during Barrovian overprint within our working area. While the intrusion of the Bergell pluton and segregating migmatitic melts (Berger et al. 1996, 2007; Burri et al. 2005) may additionally contribute to the heat budget in case of the Southern Steep belt, these effects can probably be ignored in case of our working area at the northern rim of the Lepontine dome.

Exhumation of hot eclogitic slices, combined with radioactive heat production by accreted continental crust, was proposed as a model for Barrow-type overprint within the Southern Steep Belt (Tectonic Accretion Channel model, e.g. Engi et al. 2001, Roselle et al. 2002). Rising high-temperature eclogites as a potential advective heat source are indeed available outside the working area, i.e. in form of the eclogite facies Adula nappe complex. Moreover, in the Western Alps, characterised by the occurrence of large volumes of high-pressure and ultrahigh-pressure units, such as the Gran Paradiso and Dora-Maira 
Internal Massifs, no Barrowian thermal overprint is observed (Oberhänsli et al. 2004). It seems that the rising of eclogites is not efficient enough to explain Barrovian overprint in our working area, since such eclogites are restricted to more southerly areas within the Lepontine dome, and also in view of the large temporal hiatus between high-pressure event and Barrovian overprint.

The strongest argument against advective heat transport by exhumation of eclogitic material in the northern Lepontine dome and the Tauern window is that the distribution of the HP/LT metamorphic units in the Alps is completely different from that of the areas characterised by a Barrovian overprint (Bousquet et al.2008). The latter are restricted to dome-shaped areas, such as the Lepontine dome and the Tauern window (Bousquet et al. 2008). Both the Lepontine dome and the Tauern window are characterised by massive accretion of granitoid basement units derived from the distal European margin (Sub-Penninic nappe stack; Milnes 1974; Schmid et al. 2004). Hence, Barrovian overprint is spatially coupled with exposures of large nappe-stacks of continental material, characterised by high radioactive heat production. However, one might argue that, since both these domes represent structural highs, similar Barrovian-metamorphism would be expected at depth outside these domes. A simple consideration of the volume available between the earth's surface and the Moho, which is at approximately constant depth along strike (Waldhauser et al. 1998), excludes along-strike doming of the entire crust. Hence, this doming is related to the localised accretion of large volumes of upper European basement, as is documented by the stacking of the Sub-Penninic basement nappes; in other words, doming is the direct isostatic response of such localised accretion of European upper crust (see Bousquet et al. 2008 for a more detailed discussion).

The effect of radioactive heat production is only relevant if such material is accreted at certain depths (locations with primary lower radioactive heat productions, see Jamieson et al. 1998). The most likely way to add such heat sources is the combination of subduction and subsequent thickening (e.g. Jamieson et al. 1998; Engi et al. 2001; Roselle et al. 2002; Goffé et al. 2003). Our field observations fulfil these prerequisites since subduction was followed by late-stage heating. Hence, we propose that the thermal regime during Barrovian overprint is determined by the thermal structure during the final stages of subduction and the additional heat release from radioactive decay of accreted material. However, these considerations do not quantitatively explain the observed distribution of temperatures and additional model calculations to those of Bousquet et al. (1997), Roselle et al. (2002) and Goffé et al. (2003) are necessary.

Nevertheless the field data can be discussed within the frame of the thermal evolution of the Alpine orogenic wedge (see Fig. 15). The low-temperature regime is associated with an early subduction and sediment accretion stage and led to the formation of mineral assemblages that are typical for subduction processes and related down-folding of the iso-
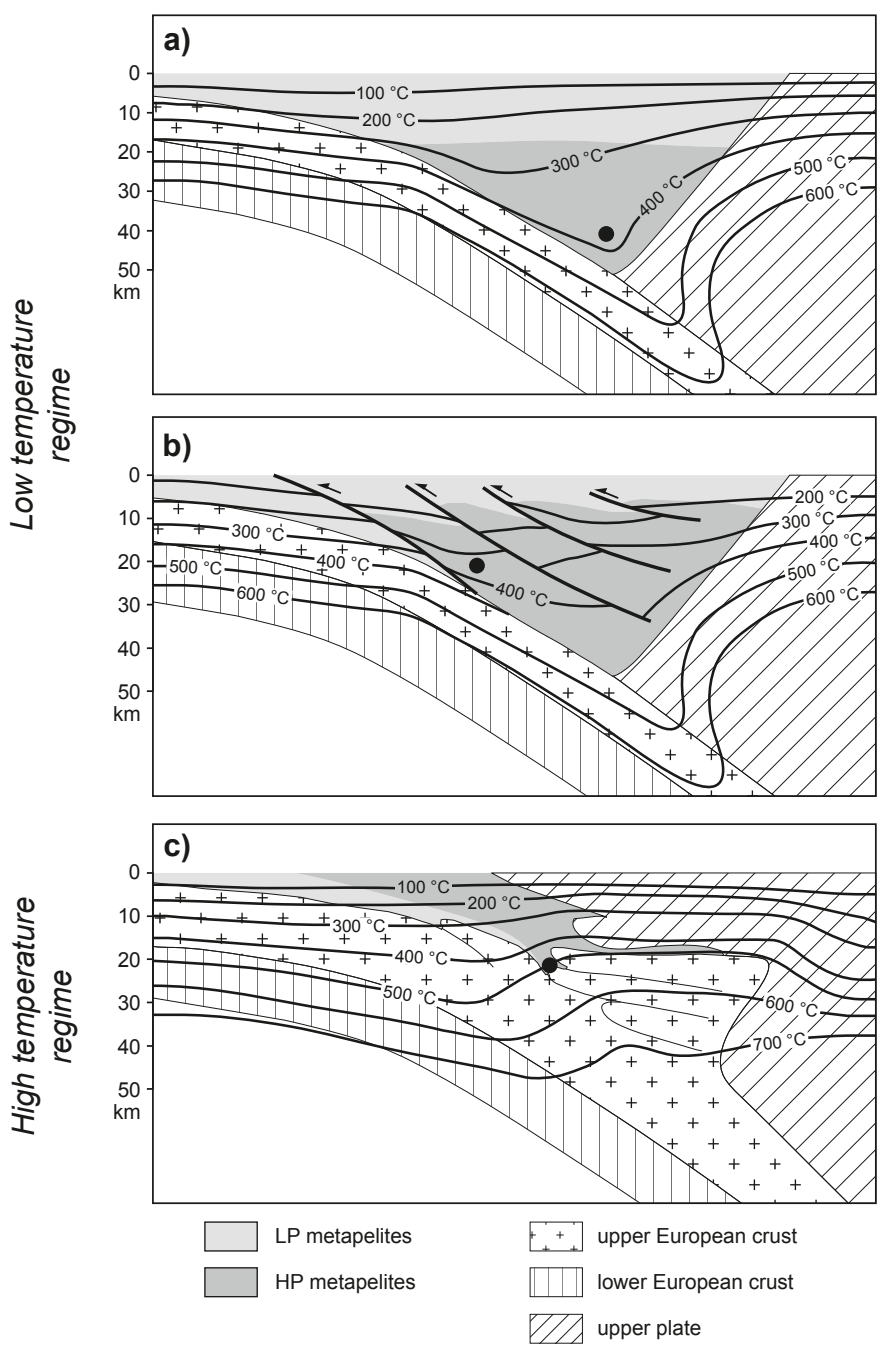

Fig. 15. Very schematic sketches, illustrating the evolution of isotherms in an orogenic wedge (inspired by Goffé et al. 2003) such as the Alps during three geodynamic stages of the orogen. Two strongly differing thermal regimes are distinguished: a low temperature (a \& b) and a high temperature regime (c). The black dot represents the location of the meta-sediments of the study area. (a) Typical pattern of isotherms during the subduction stage. The wedge is dominated by accretion of large amounts of sediments. The deeper parts of the wedge are characterised by pressure-dominated metamorphism under blueschist facies conditions. (b) Isothermal or cooling decompression during nappe-stacking, bringing HP onto LP units; the isotherms remain downbent. (c) Due to massive accretion of continental crustal material after collision, the rock composition within the wedge changes dramatically: Large amounts of upper-crustal European granitoid rocks were accumulated within the wedge (Sub-Penninic nappe stack). This accumulation of heat-producing crustal material is responsible for increasing temperatures by the up-bending of isotherms inducing the late-stage amphibolite-facies Barrovian overprint observed in the working area.

therms (Fig. 15a). During ongoing subduction, deeper parts of the orogenic wedge were thrust onto lower pressure units, a process that is accompanied with nearly isothermal or cooling decompression (Fig. 15b). The high-temperature regime (Fig. 15c) occurs after the accretion of additional continental 
middle crust that led to the formation of the Sub-Penninic nappe-stack. This temperature regime leads to the up-doming of isotherms, which cut through nearly all the structural units (Fig. 12). Therefore, we infer that the observable crosscutting isotherms are most likely related to a late stage of purely conductive heat transfer. Note that these rising isotherms, in the absence of mass transport, elegantly explain the Barrow-type amphibolite facies overprint of HP/LT units that already experienced substantial decompression before, as is the case in our study area.

\section{Conclusions}

We provided evidence for a two-stage metamorphic evolution of meta-sedimentary units derived from the Valaisan Ocean (Grava nappe) and the distal European margin (Peidener Schuppenzone) in the north-eastern part of the Lepontine dome. A first HP/LT metamorphic event under blueschist facies conditions $\left(350-400{ }^{\circ} \mathrm{C}\right.$ and $\left.1.2-1.4 \mathrm{GPa}\right)$ was associated with subduction and sediment-accretion. It was immediately followed by "cold" isothermal or cooling decompression during nappe stacking. Continent-collision-related classical Barrow-type amphibolite facies overprint $\left(500-570{ }^{\circ} \mathrm{C}\right.$ and $0.5-$ $0.8 \mathrm{GPa}$ ) represents a separate heating pulse that post-dates the D3 nappe-refolding event. It was induced by post-collisional accretion of continental crust, and it largely occurred under static conditions, partly during the initial stages of the D4 back-folding event that led to the formation of the Northern Steep Belt of the Penninic nappe pile. The two metamorphic events are separated by a time gap within our working area, estimated to be in the order of $20 \mathrm{Ma}$.

Amongst the various possible heat sources of Barrovian metamorphism we regard radiogenic heat production by accretion of continental crust during the collisional and post-collisional stages of Alpine orogeny, associated with rising isotherms, to be mainly responsible for this separate late-stage heating event at the north-eastern rim of the Lepontine dome. We propose that the Lepontine and Tauern thermal and structural domes both largely resulted from the local accretion of massive volumes of Sub-Penninic basement nappes derived from the distal European margin. This well explains the substantial Barrow-type thermal gradient observed at the north-eastern rim of the Lepontine dome, cutting across former nappe contacts almost perpendicular to strike. We emphasise, however, that in the southern parts of the Lepontine dome (Southern Steep Belt) other heat sources such as heat advection by rising eclogitic bodies and melts are probably also very important (e.g. Frey \& Ferreiro Mählmann 1999; Nagel et al. 2002; Keller et al. 2005; Berger et al. 2007).

The new data from the north-eastern rim of the Lepontine dome provide strong evidence for the former existence of a contiguous HP/LT belt, representing a second northern suture zone associated with the closure of the Valais Ocean. Moreover, relative timing constraints indicate that both HP/LT metamorphism and Barrow-type overprint were diachronous at the scale of the Alpine orogen; hence all indicators of metamorphic zonation such as index mineral zone boundaries must be strongly diachronous.

\section{Acknowledgements}

Excellent preparation of numerous samples by W. Tschudin, as well as hauling masses of rocks down the mountains by G. Derungs, including great support in the field, are gratefully acknowledged. O. Appelt and Dr. D. Rhede from the GeoForschungsZentrum Potsdam are thanked for help with microprobe analyses. A supporting field visit of A. Riemann from the University of Potsdam is appreciated. Dr. M.A. Ziemann is thanked for the introduction and support in the Raman laboratory of Potsdam University. We also thank the two reviewers J. Pleuger and M. Janak for their constructive comments and suggestions for improving this paper, and the editor N. Froitzheim for his careful handling of the manuscript. Substantial funding by the Swiss National Science Foundation (project NF-200020-113585 and precursor project NF-200020-103585) is gratefully acknowledged.

\section{REFERENCES}

Agard, P., Jolivet, L. \& Goffé, B. 2001: Tectonometamorphic evolution of the Schistes Lustrés complex: implications for the exhumation of HP and UHP rocks in the Western Alps. Bulletin de la Société Géologique de France 172, 617-636.

Allaz, J., Janots, E., Engi, M., Berger, A. \& Villa, I.M. 2007: Understanding Tertiary metamorphic ages in the northern Central Alps. Geophysical Research Abstracts 9, EGU2007-A-07684.

Ballèvre, M., Lagabrielle, Y. \& Merle, O. 1990: Tertiary ductile normal faulting as a consequence of lithospheric stacking in the Western Alps. Mémoires de la Société Géologique Suisse 1,227-236.

Baudin, T., Marquer, D. \& Persoz F. 1993: Basement-cover relationships in the Tambo nappe (Central Alps, Switzerland) - geometry, structure and kinematics. Journal of Structural Geology 15, 543-553.

Baumer,A. 1964: Geologie der gotthardmassivisch-penninischen Grenzregion im oberen Bleniotal. Geologie der Blenio-Kraftwerke. Beiträge zur Geologie der Schweiz, Geotechnische Serie 39, 105 pp.

Baumer, A., Frey, J.D., Jung, W. \& Uhr, A. 1961: Die Sedimentbedeckung des Gotthard-Massivs zwischen oberen Bleniotal und Lugnez (Vorläufige Mitteilung). Eclogae geologicae Helvetiae 54, 478-491.

Becker, H. 1993: Garnet peridotite and eclogite Sm-Nd mineral ages from the Lepontine dome (Swiss Alps) - New evidence for Eocene high-pressure metamorphism in the Central Alps. Geology 21, 599-602.

Berger, A. \& Bousquet, R. 2008: Subduction related metamorphism in the Alps: Review of isotopic ages based on petrology and their geodynamic consequences. In: Siegesmund, S. et al. (Eds.): Tectonic Aspects of the Alps-Dinarides-Carpathians system. Geological Society Special Publications $298,117-144$.

Berger, A., Rosenberg, C. \& Schmid, S.M. 1996: Ascent, emplacement and exhumation of the Bergell pluton within the Southern Steep Belt of the Central Alps. Schweizerische Mineralogische und Petrographische Mitteilungen 76,357-382.

Berger, A., Mercolli, I. \& Engi, M. 2005: The central Lepontine Alps: Notes accompanying the tectonic and petrographic map sheet Sopra Ceneri (1:100'000). Schweizerische Mineralogische und Petrographische Mitteilungen 85, 109-146.

Berger, A., Burri T., Alt-Epping, P. \& Engi, M. 2007: Tectonically controlled fluid flow and water-assisted melting in the middle crust: An example from the Central Alps. Lithos, doi:10.1016/j.lithos.2007.07.027.

Berman, R.G. 1988: Internally-consistent thermodynamic data for minerals in the system $\mathrm{Na}_{2} \mathrm{O}-\mathrm{K}_{2} \mathrm{O}-\mathrm{CaO}-\mathrm{MgO}-\mathrm{FeO}-\mathrm{Fe}_{2} \mathrm{O}_{3}-\mathrm{Al}_{2} \mathrm{O}_{3}-\mathrm{SiO}_{2}-\mathrm{TiO}_{2}-\mathrm{H}_{2} \mathrm{O}-$ $\mathrm{CO}_{2}$. Journal of Petrology 29, 445-522.

Beyssac, O., Goffé, B., Chopin, C. \& Rouzaud, J.N. 2002: Raman spectra of carbonaceous material in metasediments: a new geothermometer. Journal of Metamorphic Geology 20, 859-871. 
Beyssac, O., Bollinger, L., Avouac, J.P. \& Goffé, B. 2004: Thermal metamorphism in the lesser Himalaya of Nepal determined from Raman spectroscopy of carbonaceous material. Earth and Planetary Science Letters 225, 233-241.

Bollinger, L., Avouac, J.P., Beyssac, O., Catlos, E.J., Harrison, T.M., Grove, M., Goffé, B. \& Sapkota, S. 2004:Thermal structure and exhumation history of the Lesser Himalaya in central Nepal. Tectonics 23, TC5015, doi:10.1029/ 2003 TC001564.

Bossard, L. 1925: Der Bau der Tessiner Kulmination. Eclogae geologicae Helvetiae 19, 504-521.

Bossard, L. 1929: Zur Petrographie unterpenninischer Decken im Gebiet der Tessiner Kulmination. Schweizerische Mineralogische und Petrographische Mitteilungen 9, 47-106.

Bousquet, R., Goffé, B., Henry, P., Le Pichon, X. \& Chopin, C. 1997: Kinematic, thermal and petrological model of the Central Alps: Lepontine metamorphism in the upper crust and eclogitisation of the lower crust. Tectonophysics 273, 105-127.

Bousquet, R., Oberhänsli, R., Goffé, B., Jolivet, L. \& Vidal, O. 1998: Highpressure-low-temperature metamorphism and deformation in the Bündnerschiefer of the Engadine window: implications for the regional evolution of the eastern Central Alps. Journal of Metamorphic Geology 16, $657-674$.

Bousquet, R., Goffé, B., Vidal, O., Oberhänsli, R. \& Patriat, M. 2002: The tectono-metamorphic history of the Valaisan domain from the Western to the Central Alps: New constraints on the evolution of the Alps. Geological Society of America Bulletin 114, 207-225.

Bousquet, R., Oberhänsli, R., Goffé, B., Wiederkehr, M., Koller, F., Schmid, S.M., Schuster, R., Engi, M., Berger, A. \& Martinotti, G. 2008: Metamorphism of metasediments in the scale of an orogen: A key to the Tertiary geodynamic evolution of the Alps. In: Siegesmund, S. et al. (Eds.):Tectonic Aspects of the Alps-Dinarides-Carpathians system. Geological Society Special Publications 298, 393-411.

Brouwer, F.M. \& Engi, M. 2005: Staurolite and other aluminous phases in Alpine eclogite from the Central Swiss Alps: Analysis of domain evolution. Canadian Mineralogist 43, 105-128.

Brouwer, F.M., Burri, T., Engi, M. \& Berger, A. 2005: Eclogite relics in the Central Alps: PT-evolution, Lu-Hf ages and implications for formation of tectonic mélange zones. Schweizerische Mineralogische und Petrographische Mitteilungen 85, 147-174.

Brown, T.H., Berman, R.G. \& Perkins, E.H. 1988: GEO-CALC - Software package for calculation and display of pressure-temperature-composition phase diagrams using IBM or compatible personal computer. Computer and Geosciences 14, 279-289.

Bucher, K. \& Frey, M. 2002: Petrogenesis of metamorphic rocks. 7th edition, Springer, Berlin, 341 pp.

Bucher, S. \& Bousquet, R. 2007: Metamorphic evolution of the Briançonnais units along the ECORS-CROP profile (Western Alps): New data on metasedimentary rocks. Swiss Journal of Geosciences 100, 227242.

Bucher, S., Schmid, S.M., Bousquet, R. \& Fügenschuh, B. 2003: Late-stage deformation in a collisional orogen (Western Alps): nappe refolding, backthrusting or normal faulting? Terra Nova 15, 109-117.

Bucher S., Ulardic, C., Bousquet R., Ceriani, S., Fügenschuh B. \& Schmid, S.M. 2004: Tectonic evolution of the Briançonnais units along a transect (ECORS-CROP) through the Italian-French Western Alps. Eclogae geologicae Helvetiae 97, 321-345.

Burckhardt, C.E. 1942: Geologie und Petrographie des Basodino-Gebietes (nordwestliches Tessin). Schweizerische Mineralogische und Petrographische Mitteilungen 22, 99-188.

Burg, J.P. \& Gerya, T.V. 2005: The role of viscous heating in Barrovian metamorphism of collisional orogens: thermomechanical models and application to the Lepontine Dome in the Central Alps. Journal of Metamorphic Geology 23, 75-95.

Burkhard, M. 1988: L'Helvétique de la bordure occidentale du massif de l'Aar (évolution tectonique et métamorphique). Eclogae geologicae Helvetiae 81, 63-114.

Burri, T., Berger, A. \& Engi, M. 2005: Tertiary migmatites in the Central Alps: Regional distribution, field relations, conditions of formation, and tec- tonic implications. Schweizerische Mineralogische und Petrographische Mitteilungen 85, 215-232.

Buseck, P.R. \& Bo-Jun, H. 1985: Conversion of carbonaceous material to graphite during metamorphism. Geochimica et Cosmochimica Acta 49, 2003-2016.

Casasopra, S. 1939: Studio petrografico dello gneiss granitico Leventina. Schweizerische Mineralogische und Petrographische Mitteilungen 19, 449-709.

Chadwick, B. 1968: Deformation and Metamorphism in the Lukmanier Region, Central Switzerland. Geological Society of America Bulletin 79, $1123-1150$.

Challandes, N., Marquer, D \& Villa, I.M. 2003: Dating the evolution of C-S microstructures: a combined ${ }^{40} \mathrm{Ar} /{ }^{39} \mathrm{Ar}$ step heating and UV laserprobe analysis of the Alpine Roffna shear zone. Chemical Geology 197, $3-19$.

Chamberlain, C.P. \& Sonder, L.J. 1990: Heat-producing elements and the thermal and baric patterns of metamorphic belts. Science 250, 763-769.

Chopin, C., Seidel, E., Theye, T., Ferraris, G., Ivaldi, G. \& Catti, M. 1992: Magnesiochloritoid, and the Fe-Mg series in the chloritoid group. European Journal of Mineralogy 4, 67-76.

Dale, J. \& Holland, T.J.B. 2003: Geothermobarometry, P-T paths and metamorphic field gradients of high-pressure rocks from the Adula Nappe, Central Alps. Journal of Metamorphic Geology 21, 813-830.

Egli, W. 1966: Geologisch-petrographische Untersuchungen an der NW-Aduladecke und in der Sojaschuppe (Bleniotal, Kanton Tessin). Unpublished PhD Thesis, ETH Zürich, 160 pp.

Engi, M., Todd, C.S. \& Schmatz, D.R. 1995: Tertiary metamorphic conditions in the eastern Lepontine Alps. Schweizerische Mineralogische und Petrographische Mitteilungen 75, 347-369.

Engi, M., Berger, A. \& Roselle, G.T. 2001: Role of the tectonic accretion channel in collisional orogeny. Geology 29,1143-1146.

Ernst, W.G. 1971: Metamorphic zonations on presumably subducted lithospheric plates from Japan, California and the Alps. Contributions to Mineralogy and Petrology 34, 43-59.

Etter, U. 1987: Stratigraphische und strukturgeologische Untersuchungen im gotthardmassivischen Mesozoikum zwischen dem Lukmanierpass und der Gegend von Ilanz. Unpublished PhD Thesis, Universität Bern, $162 \mathrm{pp}$.

Fournier, M., Jolivet, L., Goffé, B. \& Dubois, R. 1991: Alpine Corsica metamorphic core complex. Tectonics 10,1173-1186.

Fox, J.S. 1975: Three-dimensional isograds from the Lukmanier-Pass, Switzerland, and their tectonic significance. Geological Magazine 112, $547-$ 564.

Frank, E. 1983: Alpine metamorphism of calcareous rocks along a crosssection in the Central Alps: occurrence and breakdown of muscovite, margarite and paragonite. Schweizerische Mineralogische und Petrographische Mitteilungen 63,37-93.

Frey, J.D. 1967: Geologie des Greinagebietes (Val Camadra - Valle Cavalasca - Val di Larciolo - Passo della Greina). Beiträge zur Geologischen Karte der Schweiz - NF 137, 112 pp.

Frey, M. 1969: Die Metamorphose des Keupers vom Tafeljura bis zum Lukanier-Gebiet. Beiträge zur Geologischen Karte der Schweiz NF 137, $160 \mathrm{pp}$.

Frey, M. 1978: Progressive low-grade metamorphism of a black shale formation, Central Swiss Alps, with special reference to Pyrophyllite and Margarite bearing assemblages. Journal of Petrology 19, 95-135.

Frey, M. \& Ferreiro Mählmann, R. 1999: Alpine metamorphism of the Central Alps. Schweizerische Mineralogische und Petrographische Mitteilungen 79, 135-154.

Frey, M., Bucher, K., Frank, E. \& Mullis, J. 1980: Alpine metamorphism along the geotraverse Basel-Chiasso - a review. Eclogae geologicae Helvetiae $73,527-546$

Frey, M., Desmons, J. \& Neubauer, F. 1999: Metamorphic map of the Alps. 1:500'000. Schweizerische Mineralogische und Petrographische Mitteilungen 79 .

Froitzheim, N., Schmid, S.M. \& Conti, P. 1994: Repeated change from crustal shortening to orogen-parallel extension in the Austroalpine units of Graubünden. Eclogae geologicae Helvetiae 87, 559-621. 
Froitzheim, N., Schmid, S.M. \& Frey, M. 1996: Mesozoic paleogeography and the timing of eclogite-facies metamorphism in the Alps: A working hypothesis. Eclogae geologicae Helvetiae 89, 81-110.

Froitzheim, N., Pleuger, J., Roller, S. \& Nagel, T. 2003: Exhumation of highand ultrahigh-pressure metamorphic rocks by slab extraction. Geology 31, 925-928.

Gillet, P. \& Goffé, B. 1988: On the signifiance of aragonite occurrence in the Western Alps. Contributions to Mineralogy and Petrology 99, 70-81.

Goffé, B. \& Bousquet, R. 1997: Ferrocarpholite, chloritoïde et lawsonite dans les métapelites des unités du Versoyen et du Petit St Bernard (zone valaisanne, Alpes occidentales). Schweizerische Mineralogische und Petrographische Mitteilungen 77, 137-147.

Goffé, B. \& Chopin, C. 1986: High-pressure metamorphism in the Western Alps: zoneography of metapelites, chronology and consequences. Schweizerische Mineralogische und Petrographische Mitteilungen 66, 41-52.

Goffé, B. \& Oberhänsli, R. 1992: Ferro- and magnesiocarpholite in the "Bündnerschiefer" of the eastern Central Alps (Grisons and Engadine Window). European Journal of Mineralogy 4, 835-838.

Goffé, B., Michard, A., Garcia-Dueñas, V., Gonzalez-Lodeiro, F., Monié, P., Campos, J., Galindo-Zaldivar, J., Jabaloy, A., Martinez-Martinez, J.M. \& Simancas, J.F. 1989: First evidence of high-pressure, low-temperature metamorphism in the Alpujarride nappes, Betic Cordilleras (SE Spain). European Journal of Mineralogy 1,139-142.

Goffé, B., Bousquet, R., Henry, P. \& Le Pichon, X. 2003: Effect of the chemical composition of the crust on the metamorphic evolution of orogenic wedges. Journal of Metamorphic Geology 21, 123-141.

Heinrich, C.A. 1982: Kyanite-eclogite to amphibolite facies evolution of hydrous mafic and pelitic rocks, Adula-nappe, Central Alps. Contributions to Mineralogy and Petrology 81,30-38.

Heinrich, C.A. 1986: Eclogite facies regional metamorphism of hydrous mafic rock in the Central Alpine Adula Nappe. Journal of Petrology 27, 123154.

Hitz, L. \& Pfiffner, O.A. 1997: Geologic interpretation of the seismic profiles of the Eastern Traverse (lines E1-E3, E7-E9): eastern Swiss Alps. In: Pfiffner et al. (Eds.): Deep Structure of the Swiss Alps - Results of NRP 20, Birkhäuser, Basel, 73-100.

Hsü, K.J. \& Briegel, U. 1991: Geologie der Schweiz - Ein Lehrbuch für den Einstieg, und eine Auseinandersetzung mit den Experten. Birkhäuser, Basel, 219 pp.

Huerta, A.D., Royden, L.H. \& Hodges, K.V.1998: The thermal structure of collisional orogens as a response to accretion, erosion, and radiogenic heating. Journal of Geophysical Research Solid Earth 103,15287-15302.

Jamieson, R.A., Beaumont, C., Fullsack, P. \& Lee, B. 1998: Barrovian regional metamorphism: where's the heat? In: Treloar, P.J. \& O'Brian, P.J. (Eds.): What drives metamorphism and metamorphic reactions? Geological Society Special Publications 138, 23-51.

Janots, E., Engi, M., Berger, A., Rubatto, D. \& Gregory, C. 2007:Texture, chemistry and age of monazite and allanite in the northern Central Alps. Geophysical Research Abstracts 9, EGU2007-A-08582.

Jenny, H., Frischknecht, G. \& Kopp, J. 1923: Geologie der Adula. Beiträge zur Geologischen Karte der Schweiz NF 51, 123 pp.

Jung, W. 1963: Die mesozoischen Sedimente am Südostrand des GotthardMassivs (zwischen Plaun la Greina und Versam). Eclogae geologicae Helvetiae 56, 653-754.

Keller, F. 1968: Mineralparagenesen und Geologie der Campo Tencia-Pizzo Forno-Gebirgsgruppe. Beiträge zur Geologischen Karte der Schweiz NF $135,71 \mathrm{pp}$.

Keller, L.M., Hess, M., Fügenschuh, B. \& Schmid, S.M. 2005: Structural and metamorphic evolution of the Camughera - Moncucco, Antrona and Monte Rosa units southwest of the Simplon line, Western Alps. Eclogae geologicae Helvetiae 98, 19-49.

Keller, L.M., Fügenschuh, B., Hess, M., Schneider, B. \& Schmid, S.M. 2006: Simplon fault zone in the Western and Central Alps: Mechanism of Neogene faulting and folding revisited. Geology 34, 317-320.

Köppel, V., Günthert, A. \& Grünenfelder, M. 1981: Patterns of U-Pb zircon and monazite ages in polymetamorphic units of the Swiss Central Alps. Schweizerische Mineralogische und Petrographische Mitteilungen 61, 97-119.
Kuhn, B.K., Reusser, E., Powell, R. \& Günther, D. 2005: Metamorphic evolution of calc-schists in the Central Alps, Switzerland. Schweizerische Mineralogische und Petrographische Mitteilungen 85, 175-190.

Kupferschmid, C. 1977: Geologie auf der Lugnezer Seite der Piz Aul-Gruppe. Eclogae geologicae Helvetiae 70,1-58.

Lihou, J.C. \& Allen, P.A. 1996: Importance of inherited rift margin structures in the early North Alpine Foreland Basin, Switzerland. Basin Research 8, 425-442.

Löw, S. 1987: Die tektono-metamorphe Entwicklung der nördlichen AdulaDecke. Beiträge zur Geologischen Karte der Schweiz NF 161, 84 pp.

Mancktelow, N.S. 1992: Neogene lateral extension during convergence in the Central Alps: evidence from interrelated faulting and backfolding around the Simplonpass (Switzerland). Tectonophysics 215, 295-317.

Mancktelow, N.S. \& Pavlis, T.L. 1994: Fold-fault relationships in low-angle detachement systems. Tectonics 13, 668-685.

Marquer, D. \& Gapais, D. 1985: Les massifs cristallins externes sur une transversale Guttannen-Val Bedretto (Alpes centrales): structure et histoire cinématique. Comptes Rendues de l'Académie des Sciences de Paris 301, 543-546.

Marquer, D., Challandes, N. \& Baudin, T. 1996: Shear zone patterns and strain distribution at the scale of a Penninic nappe: The Suretta nappe (eastern Swiss Alps). Journal of Structural Geology 18, 753-764.

Massonne, H.-J. 1995: Experimental and petrogenetic study of UHPM. In: Coleman, R.G. \& Wang, X. (Eds): Ultra-high pressure metamorphism. Cambridge University Press, 159-181.

Mayerat Demarne, A.-M. 1994: Analyse structurale de la zone frontale de la nappe de Tambo (Pennique, Grisons, Suisse). Beiträge zur Geologischen Karte der Schweiz NF 165, 68 pp.

Mercolli, I., Biino, G.G. \& Abrecht, J. 1994: The lithostratigraphy of the preMesozoic basement of the Gotthard massif - a review. Schweizerische Mineralogische und Petrographische Mitteilungen 74, 29-40.

Merle, O., Cobbold, P.R. \& Schmid, S.M. 1989: Tertiary kinematics in the Lepontine Alps. In: Coward, M.P. et al. (Eds.): Alpine Tectonics. Geological Society Special Publications 45,113-134.

Meyre, C., De Capitani, C. \& Partzsch, J.H. 1997: A ternary solid solution model for omphacite and its application to geothermobarometry of eclogites from the Middle Adula nappe (Central Alps, Switzerland). Journal of Metamorphic Geology 15, 687-700.

Milnes, A.G. 1974: Structure of the Pennine zone (Central Alps) - new working hypothesis. Geological Society of America Bulletin 85, 1727-1732.

Milnes, A.G. 1976: Strukturelle Probleme im Bereich der Schweizer Geotraverse - das Lukmanier-Massiv. Schweizerische Mineralogische und Petrographische Mitteilungen 56, 615-618.

Milnes, A.G. \& Schmutz, H.-U. 1978: Structure and history of the Suretta nappe (Pennine zone, Central Alps) - a field study. Eclogae geologicae Helvetiae 71, 19-33.

Nabholz, W.K. 1945: Geologie der Bündnerschiefergebirge zwischen Rheinwald, Valser- und Safiental. Eclogae geologicae Helvetiae 38, 1-119.

Nagel, T., de Capitani, C., Frey, M., Froitzheim, N., Stünitz, H. \& Schmid, S.M. 2002: Structural and metamorphic evolution during rapid exhumation in the Lepontine dome (southern Simano and Adula nappes, Central Alps, Switzerland). Eclogae geologicae Helvetiae 95, 301-321.

Nänny, P. 1948: Zur Geologie der Prättigauschiefer zwischen Rhätikon und Plessur. Mitteilungen aus dem Geologischen Institut der Eidgenössischen Technischen Hochschule und der Universität Zürich 30,127 pp.

Niggli,E. 1970: Alpine Metamorphose und alpine Gebirgsbildung. Fortschritte der Mineralogie 47, 16-26.

Niggli, E. \& Niggli, C. 1965: Karten der Verbreitung einiger Mineralien der alpidischen Metamorphose in den Schweizer Alpen (Stilpnomelan, Alkali-Amphibol, Chloritoid, Staurolith, Disthen, Sillimanit). Eclogae geologicae Helvetiae 58, 335-368.

Niggli,E. \& Zwart, H.J.1973: Metamorphic Map of the Alps, scale 1:1'000'000. Subcommision for the Cartography of the Metamorphic Belts of the World. Sheet 17 of the Metamorphic Map of Europe. Leiden/UNESCO, Paris.

Niggli, P., Preiswerk, H., Grütter, O., Bossard, L. \& Kündig, E. 1936: Geologische Beschreibung der Tessineralpen zwischen Maggia und Bleniotal. Beiträge zur Geologischen Karte der Schweiz NF 71, 190 pp. 
Nimis, P. \& Trommsdorff, V. 2001: Revised thermobarometry of Alpe Arami and other garnet peridotites from the Central Alps. Journal of Petrology 42,103-115.

Oberhänsli, R. 1994: Subducted and obducted ophiolites of the Central Alps: Paleotectonic implications deduced by their distribution and metamorphic overprint. Lithos 33, 109-118.

Oberhänsli, R., Goffé, B. \& Bousquet, R. 1995: Record of a HP-LT metamorphic evolution in the Valais zone: Geodynamic implications. In: Lombardo, B. (Ed.): Studies on metamorphic rocks and minerals of the western Alps. A Volume in Memory of Ugo Pognante. Bolletino Museo Regionale di Scienze Naturali, Torino, 13, 221-239.

Oberhänsli, R., Bousquet, R. \& Goffé, B. 2003: Comment to «Chloritoid composition and formation in the eastern Central Alps: a comparison between Penninic and Helvetic occurrences » by M. Rahn, M. Steinmann \& M. Frey. Schweizerische Mineralogische und Petrographische Mitteilungen 83,341-344.

Oberhänsli, R., Bousquet, R., Engi, M., Goffé, B., Gosso, G., Handy, M., Höck, V., Koller, F., Lardeaux, J.-M., Polino, R., Rossi, P., Schuster, R., Schwartz, S. \& Spalla, M.I. 2004: Metamorphic structure of the Alps. In: Oberhänsli, R. (Ed.): Explanatory note to the map «Metamorphic structure of the Alps, 1:1'000'000», Commission for the Geological Map of the World, Paris. Mitteilungen der Österreichischen Mineralogischen Gesellschaft, 149.

Partzsch, J.H. 1998: The tectono-metamorphic evolution of the middle Adula nappe, Central Alps, Switzerland. Unpublished PhD Thesis, Universität Basel, 142 pp.

Peacock, S.M. 1996: Thermal and petrologic structure of subduction zones. In: G.E. Bebout et al. (Eds.): Subduction from Top to Bottom. American Geophysical Union, Washington D.C., 119-133.

Pesquera, A. \& Velasco, F. 1988: Metamorphism of the Paleozoic Cinco Villas massif (Basque Pyrenees) - Illite crystallinity and graphitization degree. Mineralogical Magazine 52, 615-625.

Pfiffner, O.A. 1977: Tektonische Untersuchungen im Infrahelvetikum der Ostschweiz. Mitteilungen aus dem Geologischen Institut der Eidgenössischen Technischen Hochschule und der Universität Zürich 217, $432 \mathrm{pp}$.

Pfiffner, O.A., Sahli, S. \& Stäuble, M. 1997: Compression and uplift of the external massifs in the Helvetic zone. In: Pfiffner et al. (Eds.): Deep Structure of the Swiss Alps - Results of NRP 20, Birkhäuser, Basel, 139-153.

Platt, J.P. 1986: Dynamics of orogenic wedges and the uplift of high-pressure metamorphic rocks. Geological Society of America Bulletin 97, 10371053.

Pleuger, J., Hundenborn, R., Kremer, K., Babinka, S., Kurz, W., Jansen, E. \& Froitzheim, N. 2003: Structural evolution of Adula nappe, Misox zone, and Tambo nappe in the San Bernardino area: Constraints for the exhumation of the Adula eclogites. Mitteilungen der Österreichischen Geologischen Gesellschaft 94 (2001), 99-122.

Pleuger, J., Nagel, T.J., Walter, J.M., Jansen, E. \& Froitzheim, N. 2008: On the role and importance of orogen-parallel and -perpendicular extension, transcurrent shearing, and backthrusting in the Monte Rosa nappe and the Southern Steep Belt of the Alps (Penninic zone, Switzerland and Italy). In: Siegesmund, S. et al. (Eds.): Tectonic Aspects of the Alps-Dinarides-Carpathians system. Geological Society Special Publications 298, 251-280.

Probst, P. 1980: Die Bündnerschiefer des nördlichen Penninikums zwischen Valser Tal und Passo di San Giacomo. Beiträge zur Geologischen Karte der Schweiz NF 153, 64 pp.

Rahn, M.K., Steinmann, M. \& Frey, M. 2003: Chloritoid composition and formation in the eastern Central Alps: a comparison between Penninic and Helvetic occurrences. Schweizerische Mineralogische und Petrographische Mitteilungen 82, 409-426.

Rimmelé, G., Jolivet, L., Oberhänsli, R. \& Goffé, B. 2003: Deformation history of the high-pressure Lycian Nappes and implications for tectonic evolution of SW Turkey. Tectonics 22, doi:10.1029/2001TC901041.

Robyr, M., Vonlanthen, P., Baumgartner, L.P. \& Grobety, B. 2007: Growth mechanism of snowball garnets from the Lukmanier Pass area (Central Alps, Switzerland): a combined mCT/EPMA/EBSD study. Terra Nova 19, 240-244.
Roselle, G.T., Thüring, M. \& Engi, M. 2002: MELONPIT:A finite element code for simulating tectonic mass movement and heat flow within subduction zones. American Journal of Science 302, 381-409.

Rütti, R., Maxelon, M. \& Mancktelow, N.S. 2005: Structure and kinematics of the northern Simano Nappe, Central Alps, Switzerland. Eclogae geologicae Helvetiae 98, 63-81.

Rütti, R., Marquer, D. \& Thompson, A.B. 2008: Tertiary tectono-metamorphic evolution of the European margin during Alpine collision: Example of the Leventina Nappe (Central Alps, Switzerland). Swiss Journal of Geosciences doi: 10.1007/s00015-008-1278-9.

Schmid, S.M., Zingg, A. \& Handy, M. 1987: The kinematics of movements along the Insubric line and the emplacement of the Ivrea zone. Tectonophysics $135,47-66$.

Schmid, S.M., Rück, P. \& Schreurs, G. 1990: The significance of the Schams nappes for the reconstruction of the paleotectonic and orogenic evolution of the Penninic zone along the NFP-20 East traverse (Grisons, eastern Switzerland). In: Roure, et al. (Eds.): Deep structure of the Alps, Mémoire de la Société de France, Paris, 156, 263-287.

Schmid, S.M., Pfiffner, O.A., Froitzheim, N., Schönborn, G. \& Kissling, E. 1996: Geophysical-geological transect and tectonic evolution of the Swiss-Italian Alps. Tectonics 15, 1036-1064.

Schmid, S.M., Pfiffner, O.A., Schönborn, G., Froitzheim, N. \& Kissling, E. 1997a: Integrated cross section and tectonic evolution of the Alps along the Eastern Traverse. In: Pfiffner et al. (Eds.): Deep Structure of the Swiss Alps - Results of NRP 20, Birkhäuser, Basel, 289-304.

Schmid, S.M., Pfiffner, O.A. \& Schreurs, G. 1997b: Rifting and collision in the Penninic zone of eastern Switzerland. In: Pfiffner et al. (Eds.): Deep Structure of the Swiss Alps - Results of NRP 20, Birkhäuser, Basel, $160-185$.

Schmid, S.M., Fügenschuh, B., Kissling, E. \& Schuster, R. 2004: Tectonic map and overall architecture of the Alpine orogen. Eclogae geologicae Helvetiae 97, 93-117.

Schreurs, G. 1993: Structural analysis of the Schams nappes and adjacent tectonic units: implications for the orogenic evolution of the Pennine zone in eastern Switzerland. Bulletin de da Société Géologique de France 164, 415-435.

Spicher, A. 1980: Tektonische Karte der Schweiz, 1:500'000. Schweizerische Geologische Kommission, Bern.

Stampfli, G.M. 1993: Le Briançonnais: terrain exotique dans les Alpes? Eclogae geologicae Helvetiae 86, 1-45.

Stampfli, G.M., Mosar, J., Marquer, D., Marchant, R., Baudin, T. \& Borel, G. 1998: Subduction and obduction processes in the Swiss Alps. In:Vauchez, A. \& Meissner, R. (Eds): Continents and their mantle root. Tectonophysics 296, 159-204.

Steck, A. 1984: Structures de deformations tertiaires dans les Alpes centrales (transversale Aar-Simplon-Ossola). Eclogae geologicae Helvetiae 77, $55-100$.

Steck, A. 1990: Une carte des zones de cisaillement ductile des Alpes Centrales. Eclogae geologicae Helvetiae 83, 603-627.

Steck, A. \& Hunziker, J.C. 1994: The Tertiary structural and thermal evolution of the Central Alps - Compressional and extensional structures in an orogenic belt. Tectonophysics 238, 229-254.

Steiger, R.H. 1962: Petrographie und Geologie des südlichen Gotthardmassivs zwischen St. Gotthard- und Lukmanierpass. Schweizerische Mineralogische und Petrographische Mitteilungen 64,381-577.

Steinmann, M. 1994a: Die nordpenninischen Bündnerschiefer der Zentralalpen Graubündens: Tektonik, Stratigraphie und Beckenentwicklung. Unpublished PhD Thesis, ETH Zürich, 220 pp.

Steinmann, M. 1994b: Ein Beckenmodell für das Nordpenninikum der Ostschweiz. Jahrbuch der Geologischen Bundesanstalt 137, 675-721.

Thakur, V.C. 1971: The structural and metamorphic history of the Mesozoic and pre-Mesozoic basement rocks of the Molare region, Ticino, Switzerland. Unpublished PhD Thesis, Imperial college of London, 229 pp.

Thakur, V.C. 1973: Events in the Alpine deformation and metamorphism in the northern Pennine zone and southern Gotthard massif regions, Switzerland. Geologische Rundschau 62, 549-563.

Todd, C.S. \& Engi, M. 1997: Metamorphic field gradients in the Central Alps. Journal of Metamorphic Geology 15, 513-530. 
Trommsdorff, V. 1966: Progressive Metamorphose kieseliger Karbonatgesteine in den Zentralalpen zwischen Bernina und Simplon. Schweizerische Mineralogische und Petrographische Mitteilungen 46, 431-460.

Trommsdorff, V. 1990: Metamorphism and tectonics in the Central Alps: The Alpine lithospheric mélange of Cima Lunga and Adula. Memorie della Societa Geologica Italiana 45, 39-49.

Trotet, F., Goffé, B., Vidal, O. \& Jolivet, L. 2006: Evidence of retrograde Mgcarpholite in the Phyllite-Quartzite nappe of Peloponnese from thermobarometric modelisation - geodynamic implications. Geodinamica Acta 19, 323-343.

Trümpy, R. 1960: Paleotectonic evolution of the Central and Western Alps. Geological Society of America Bulletin 71,843-908.

Trümpy, R. 1980: Geology of Switzerland - a guide-book. Part A: An outline of the Geology of Switzerland. Wepf, Basel, 104 pp.

Uhr, A. Unpublished: Geologische Untersuchungen im Gebiet des Piz Terri (Kt. Tessin und Graubünden). Textmanuskript, hinterlegt beim BWG, Bern-Ittigen.

Vidal, O., Goffé, B. \& Theye, T. 1992: Experimental study of the stability of sudoite and magnesiocarpholite and calculation of a new petrogenetic grid for the system $\mathrm{FeO}-\mathrm{MgO}-\mathrm{Al}_{2} \mathrm{O}_{3}-\mathrm{SiO}_{2}-\mathrm{H}_{2} \mathrm{O}$. Journal of Metamorphic Geology 10, 603-614.

Vidal, O. \& Theye, T. 1996: Comment on "Petrology of Fe-Mg-carpholite-bearing metasediments from northeast Oman". Journal of Metamorphic Geology 14, 381-386.
Voll, G. 1976: Structural Studies of the Valser Rhine Valley and the Lukmanier Region and their Importance for the nappe Structure of the Central Swiss Alps. Schweizerische Mineralogische und Petrographische Mitteilungen 56, 619-626.

von Blanckenburg, F. \& Davies, J.H. 1995: Slab breakoff: A model for syncollisional magmatism and tectonics in the Alps. Tectonics 14, 120-131.

Waldhauser, F., Kissling, E., Ansorge, J. \& Mueller, S. 1998: Three-dimensional interface modelling with two-dimensional seismic data: the Alpine crustmantle boundary. Geophysical Journal International 135, 264-278.

Weh, M. \& Froitzheim, N. 2001: Penninic cover nappes in the Prättigau halfwindow (Eastern Switzerland): Structure and tectonic evolution. Eclogae geologicae Helvetiae 94, 237-252.

Wenk, E. 1962: Plagioklas als Indexmineral in den Zentralalpen. Schweizerische Mineralogische und Petrographische Mitteilungen 42,139-152.

Wenk, E. 1970: Zur Regionalmetamorphose und Ultrametamorphose im Lepontin. Fortschritte der Mineralogie 47, 34-51.

Wiederkehr, M. 2004: Strukturelle und metamorphe Entwicklung der Metasedimente am Kontakt Briançonnais - Piemont-Liguria, Val Madris, Avers/GR. Unpublished Diploma Thesis, Universität Basel. 145 pp.

Manuscript received February 1,2008

Revision accepted May 26, 2008

Published Online first November 13, 2008

Editorial Handling: Nikolaus Froitzheim \& Stefan Bucher 